\title{
LA-UR- $99-5521$
}

\author{
ACTINIDE CHEMISTRY IN THE \\ EMIC/AICl ROOM TEMPERATURE $_{3}$ \\ IONIC LIQUID \\ David A. Costa \\ Wayne H. Smith \\ Los Alamos National Laboratory \\ Los Alamos, NM 87544
}

Room temperature ionic liquids (RTIL) are a relatively new class of solvents whose unique set of chemical and physical properties hold the promise of making revolutionary changes in many traditional chemical processes. We have previously reported on the redox behavior of uranyl chloride in room temperature acidic 1ethyl-3-methyl imidazolium chloride by electrochemical and spectroscopic techniques. ${ }^{1,2}$ The uranyl moiety is unstable to oxygen loss in this melt with the concomitant growth of a uranium $(\mathrm{V})$ chloride species. We proposed that an equilibrium is established between the Lewis acidic $\mathrm{Al}_{2} \mathrm{Cl}_{7}$ and the uranium oxy-chloride species. Similar behavior may be expected for plutonium oxide species. We have demonstrated that a basic EMIC/AICl ${ }_{3}$ solution of $\mathrm{PuCl}_{3}$ displays one reversible oxidation and an irreversible reduction. The reversible wave has been confirmed to be associated with the $\mathrm{Pu}$ (III)/ $\mathrm{Pu}$ (IV) redox couple by comparison with the $\mathrm{CV}$ of an authentic sample of $\mathrm{Cs}_{2} \mathrm{PuCl}_{6}$. The irreversible reduction wave is believed to come from the reduction of a plutonium oxide contaminant. In this talk we will focus on our work on the chemistry of plutonium complexes in room temperature ionic liquids (i.e. $\mathrm{EMIC/AICl} l_{3}$ and $\mathrm{EMIBF}_{4}$ ).

\footnotetext{
'Anderson, C.J.; Choppin, G.R.; Pruett, D.J.; Costa, D.A.; Smith, W.H. Rad. Chem. Acta. In press.
}

${ }^{2}$ David A. Costa, Wayne H. Smith; Proceedings of the Eleventh International Symposium on Molten Salts, P.C. Trulove, H.C. De Long, G.R. Stafford, S. Deki, PV 9811, p. 266, The Electrochemical Proceedings Series, Pennington, NJ 1998. 


\section{DISCLAIMER}

This report was prepared as an account of work sponsored by an agency of the United States Government. Neither the United States Government nor any agency thereof, nor any of their employees, make any warranty, express or implied, or assumes any legal liability or responsibility for the accuracy, completeness, or usefulness of any information, apparatus, product, or process disclosed, or represents that its use would not infringe privately owned rights. Reference herein to any specific commercial product, process, or service by trade name, trademark, manufacturer, or otherwise does not necessarily constitute or imply its endorsement, recommendation, or favoring by the United States Government or any agency thereof. The views and opinions of authors expressed herein do not necessarily state or reflect those of the United States Government or any agency thereof. 


\section{DISCLAIMER}

Portions of this document may be illegible in electronic image products. Images are produced from the best available original document. 


\title{
ACTINIDE CHEMISTRY IN THE

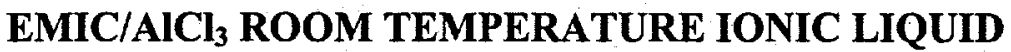

\author{
David A. Costa \\ Wayne H. Smith \\ Harry Dewey \\ Los Alamos National Laboratory \\ Los Alamos, NM 87545
}

\section{INTRODUCTION}

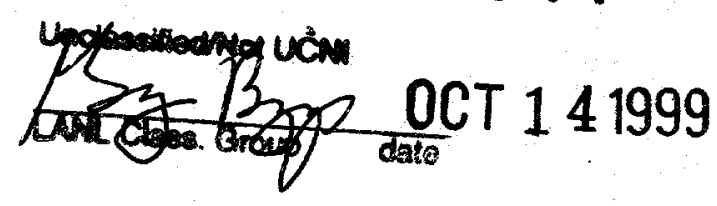

RECEIVED

DEC 132000

OSTI

\section{Actinide chemistrv in RTIL systems (Why?)}

Room temperature ionic liquids (RTIL) have potential throughout the nuclear industry in the recovery and purification of actinide elements, as reactor components, as waste disposal forms, and potentially as media for the storage and/or separation of spent nuclear fuels. Due to their unique dissolution properties, RTIL's can be used as substitutes for solvents currently used in the extraction of uranium from native ores, and in the dissolution and reprocessing of spent nuclear fuels. Potential benefits include greater uranium and plutonium recovery efficiencies and the ability to recycle the solvent, leading to a decrease in waste generation and lower overall production costs. Another potential area of interest is in the use of RTIL's as solvents for the recovery and purification of actinide elements. Many of the current recovery processes are redox based and are carried out in high temperature molten salt systems. These processes are inefficient, require extreme operating conditions and generate large quantities of contaminated residues. Substituting RTIL's for the high temperature melts and performing these reactions at ambient temperature would allow for greater control over the reactions, leading to much higher yields and higher final product purity. The development of room temperature, low pressure processes would mitigate the safety concerns associated with high temperature operations. Also the ability to recycle these extremely low vapor pressure solvents would lead to significantly less waste generation. Finally, the unique ability to adjust the acid/base properties of some of the RTIL melts, coupled with the lack of interference from hydrolysis reactions, creates an opportunity to obtain much more detailed information on the fundamental chemical behavior of actinide compounds. This knowledge can be instrumental in the development of the next generation of actinide separation and purification processes.

Research efforts in our laboratory focus on determining the chemical properties (i.e. solubilities, complexation, redox properties, etc) of actinide species in RTIL systems. We are currently involved in RTIL projects ranging from the spectroscopic characterization of actinide complexes by $\mathrm{O}^{17} \mathrm{NMR}$, low temperature UV-Vis, and EXAFS, to the enhanced dissolution and separation of actinide oxides in room temperature ionic liquids. Further, we have extensive experience in the electrochemical characterization of actinide complexes in ionic melts. Ultimately we would like to be able to compare the chemistries observed in the RTIL systems with the high temperature molten salt systems 
currently in use in the actinide recovery and purification processes. The results of our study will allow us to evaluate the potential of RTIL systems as alternative solvents in the nuclear industry.

\section{Background}

\section{A. Actinides in RTILs}

Published studies of actinide systems in room temperature ionic liquid (RTIL) solvent systems have been limited to neptunium (1) and uranium (2),(3). In basic melts the reduction of U (IV) to U (III) was found to be reversible and U (IV) and U (III) were determined to be present as the hexachloro anions over the entire basic range (4). In acidic $\mathrm{AlCl}_{3}-\mathrm{BPC}, \mathrm{U}$ (IV) is stable over the entire acidic range, existing as $\mathrm{UCl}_{3}{ }^{+}, \mathrm{UCl}_{2}{ }^{2+}$, and $\mathrm{UCl}^{3+}$, with increasing acidity (i.e., decreasing $\mathrm{Cl}^{-}$concentration). Similar studies have shown that $U(V)$ is stable in all acidic compositions (4). The spectrum of $U(V)$ in an acidic melt is similar to that recorded in $\mathrm{SOCl}_{2}(5)$ and nitromethane (6). Uranyl (VI) is stable in basic $\mathrm{AlCl}_{3}-\mathrm{BPC}$ and $\mathrm{AlCl}_{3}$-EMIC forming chloro-complexes of the type $\mathrm{UO}_{2} \mathrm{Cl}_{4+\mathrm{x}}{ }^{(2+\mathrm{x})-}$ which are irreversibly reduced to $\mathrm{UCl}_{6}{ }^{2-} . \mathrm{U}(\mathrm{VI})$ introduced as $\mathrm{UO}_{3}$ to the acidic high temperature ionic liquid $\mathrm{AlCl}_{3}-\mathrm{NaCl}$ reacted to give $\mathrm{U}(\mathrm{V})(7)$.

The U(IV)/U(III) couple exhibits reversible electrochemistry in basic $\mathrm{AlCl}_{3}-\mathrm{EMIC}$ melts. Potentiometric measurements for this couple as a function of $\mathrm{Cl}^{-}$concentration suggest that both species are present as the hexachloro anions (8). This behavior differs from that of the closely related element neptunium as, for solutions greater than $57 \mathrm{~mol} \% \mathrm{AlCl}_{3}$, $\mathrm{Np}(\mathrm{III})$ was found to be the only stable species (9). In basic melts U(V) is reduced by "free" chloride to $\mathrm{U}(\mathrm{IV})(10)$. Uranyl $\left(\mathrm{UO}_{2}{ }^{2+}\right)$ was found to be stable in basic $\mathrm{AlCl}_{3}-\mathrm{BPC}$ (11) and $\mathrm{AlCl}_{3}$-EMIC (12) forming chloro-complexes of the type $\mathrm{UO}_{2} \mathrm{Cl}_{4-\mathrm{x}}{ }^{(2+x)-}$ which were reduced irreversibly at the electrode to $\mathrm{UCl}_{6}{ }^{2-}$.

The recent patent applications (13) (14) for the dissolution of $\mathrm{UO}_{2}$ as uranyl in RTIL systems, as an alternative to the Purex process, have heightened our interest into the chemistry of these systems. The limited data available on the stability of uranyl in acidic RTIL systems prompted our spectroscopic and electrochemical study of $\mathrm{UO}_{2}{ }^{2+}$ in acidic $\mathrm{AlCl}_{3}$-EMIC (15) (16). In this work we demonstrated that in acidic $\mathrm{AlCl}_{3}$-EMIC ionic liquids the uranyl moiety is reduced over several days to a $\mathrm{U}(\mathrm{V})$ non-oxo species. We proposed a mechanism based on both acid-base and redox reactions between the melt components and the uranium species. This mechanism involves the formation and subsequent reaction of transitory uranium oxy-chloride complexes. In the present paper, we will present further evidence in support of our uranium mechanism and extend this work to include the spectroscopy of uranyl in low temperature glasses and our initial investigations into the electrochemistry of plutonium in the $\mathrm{EMIC} / \mathrm{AlCl}_{3} \mathrm{RTILs}$.

\section{B. Chemistry and Electrochemistry of Plutonium}

i. Equilibria. A full review of this chemistry is well beyond the scope of this paper, but the interested reader is referred to the Plutonium Handbook (17) and references therein for further detail. The solution chemistry of plutonium is very complex and 
unique among the elements. Due to the interplay between thermodynamic and kinetic drivers, plutonium can coexist in appreciable concentrations in each of its four oxidation states, $\mathrm{Pu}^{3+}, \mathrm{Pu}^{4+}, \mathrm{PuO}^{2+}$, and $\mathrm{PuO}_{2}{ }^{2+}$, within a single solution.

$\mathrm{Both} \mathrm{Pu}(\mathrm{IV})$ and $\mathrm{Pu}(\mathrm{V})$ complexes have a thermodynamic tendency to disproportionate and the kinetics of breaking the $\mathrm{Pu}-\mathrm{O}$ bond are much slower than reactions involving electron transfers. The disproportionation reaction and associated equilibrium equations of $\mathrm{Pu}(\mathrm{IV})$ is shown below:

$$
\begin{gathered}
3 \mathrm{Pu}^{4+}+2 \mathrm{H}_{2} \mathrm{O} \leftrightarrow 2 \mathrm{Pu}^{3+}+\mathrm{PuO}_{2}{ }^{2+}+4 \mathrm{H}^{+} \\
\mathrm{K}=\frac{\left[\mathrm{Pu}(\mathrm{III})^{2}[\mathrm{Pu}(\mathrm{VI})]\left[\mathrm{H}^{+}\right]^{4}\right.}{\left[\mathrm{Pu}^{4+}\right]^{3}}
\end{gathered}
$$

The value of $\mathrm{K}$ in both $1 \mathrm{M}$ perchloric and hydrochloric acid has been reported by Rabineau and Cowan (18) to be near 0.0089 . In $0.002 \mathrm{M} \mathrm{HCl}$ this equilibrium is established after $200 \mathrm{hr}$ with the relative concentrations of $\mathrm{Pu}^{3+}, \mathrm{Pu}^{4+}, \mathrm{PuO}^{2+}$, and $\mathrm{PuO}_{2}{ }^{2+}$ being $26.3 \%, 62.7 \%, 0.5 \%$, and $10.5 \%$, respectively. Although this equilibrium is effected by the stabilization of Pu (IV) through complexation, it generally holds that the more acidic the solution the less the extent of the disproportionation. $\mathrm{Pu}(\mathrm{V})$ has also been shown to disproportionate into $\mathrm{Pu}(\mathrm{VI})$ and $\mathrm{Pu}(\mathrm{III})$ with the overall rate being directly proportional to the hydrogen ion concentration. The dependence of both of these disproportionation mechanisms on $\left[\mathrm{H}^{+}\right]$would seem to indicate that $\mathrm{Pu}(\mathrm{IV})$ and $\mathrm{Pu}(\mathrm{V})$ should be very stable in the aprotic RTIL systems.

ii. Redox Chemistry. All of the aqueous schemes currently in use for the purification of plutonium rely on the selective extraction of $\mathrm{Pu}$ in various oxidation states from solution. Methods for the control of both uranium and plutonium oxidation states have therefore received considerable attention (17 above). It is apparent, as expected, that the energy associated with the making and breaking of the metal-oxo bonds plays a very important role in the redox chemistry of these species. Thus, the reduction of $\mathrm{Pu}(\mathrm{VI})$ and $\mathrm{Pu}(\mathrm{V})$ to the non-oxo $\mathrm{Pu}$ (IV) and $\mathrm{Pu}(\mathrm{III})$ are slow while electron transfers between these pairs are expected to be facile.

iii. Complexation. Complexation chemistry is more important in plutonium chemistry than in either uranium or neptunium chemistry due to its smaller ionic radius. The complex forming order for $\mathrm{Pu}$ is

$$
\mathrm{Pu}^{4+}>\mathrm{Pu}^{3+}>\mathrm{PuO}_{2}{ }^{2+}>\mathrm{PuO}_{2}{ }^{+}
$$

Spectroscopic techniques provide a valuable insight into the complexation chemistry of the actinides. For example, the absorption spectra of $\mathrm{Pu}(\mathrm{VI})$ shows a distinct absorbance at $830 \mathrm{~nm}$ in $\mathrm{HNO}_{3}$ but no absorbance at this wavelength in nitromethane.

The obvious differences in these spectra have been ascribed to the different symmetries of the ligand fields (see reference 17 above). 
iv. High Temperature Molten Salt Chemistry. To data most of the work in high temperature systems has focused on uranium. There have been several studies of $\mathrm{Pu}$ in chloride based melts (ie. $\mathrm{LiCl}-\mathrm{CsCl}, \mathrm{LiCl}-\mathrm{KCl}$ ) and the absorption spectra recorded in these melts are a good starting point for the determination of oxidation states ( $17 \mathrm{above}$ ). Several studies have been performed to determine the phase equilibria of plutoniumalkali/alkali earth salt systems. These studies have shown the presence of relatively lowmelting point eutectics in nearly all systems. The importance of selective extraction of actinides from aqueous systems cannot be overestimated. Extraction schemes are limited in high temperature melts due to the fragility of the organic extractants. One system of note is the $\mathrm{LiCl}-\mathrm{KCl}-\mathrm{AlCl}_{3}$ ternary melt, which forms two phases from $350-775 \mathrm{C}$. The upper phase consists mainly of $\mathrm{KAlCl}_{4}$ and has a 40 fold greater extraction coefficient for U(IV) over PU(III).

\section{EXPERIMENTAL}

EMIC was prepared by the method of Smith(19). $\mathrm{AlCl}_{3}$ (Aldrich) was purified by sublimation. All uranium synthesis and electrochemical experiments were performed inside a Vacuum Atmospheres Co. drybox under a He atmosphere. Pu experiments were conducted under argon in specially designed negative pressure inert glove boxes.

Electrochemical experiments were performed on a BAS CV-50 and PAR 273A electrochemical analyzers in a three-electrode cell. The current carrying electrodes in this system consisted of a $3 \mathrm{~mm}$ diameter glassy carbon working electrode (Bioanalytical Systems), and a $0.5 \mathrm{~mm} \mathrm{Pt}$ wire spiral auxiliary electrode. The reference electrode was a $1 \mathrm{~mm}$ diameter $\mathrm{Al}$ wire immersed in a 40/60 basic melt and separated from the working electrode by a medium porosity glass frit. Absorption spectra were recorded on a Perkin Elmer Lambda 19 spectrometer. Fluorescence measurements were taken on a Specs Industries Fluorolog II with the cell maintained under a blanket of liquid nitrogen throughout the experiment.

\section{RESULTS AND DISCUSSION.}

\section{A. Validation of $\mathrm{UO}_{2}{ }^{2+}$ reaction scheme.}

In previous publications we have demonstrated that in an acidic $\mathrm{AlCl}_{3}-\mathrm{EMIC}$ ionic liquid the uranyl moiety is reduced by the inorganic constituents of the RTIL over several days, or through a combination of heterogeneous electrochemistry and melt chemistry in several minutes, to a $U(V)$ non-oxo species (15 above). In figure 2 we present multicyclic voltammograms of uranyl chloride in an acidic $\mathrm{EMIC} / \mathrm{AlCl}_{3}$ ionic liquid. Note the rapid change that occurs in the uranium chemistry after several polarization cycles. We proposed a mechanism (figure 3 ), based upon electrochemical and spectroscopic investigations, to explain both the hetero- and homogeneous reactions. This reaction scheme invokes both acid-base and redox reactions between the melt components and the uranium species, and involves the formation and subsequent reaction 
of transitory uranium oxy-chloride complexes. Examples of shifts in redox potentials of metal complexes with changes in the ligand environment are ubiquitous in organometallic chemistry. Addition of one dinegative oxygen to $\mathrm{U}^{6+}$ should result in a negative shift in the reduction potential; addition of a second oxygen is expected to result in a further negative shift. Analysis of the $\mathrm{UO}_{2}{ }^{2+}$ voltammetry in this light, and in comparison to that of pristine $\mathrm{UCl}_{4}$, has led to the assignment of the redox potentials for the $\mathrm{UO}_{2} \mathrm{Cl}_{2}$ voltammorgam. In this talk we will further develop this mechanism through the presentation of corroborating electrochemical and spectroscopic detail.

Several tests of our proposed scheme are readily apparent. We assume, from our previous work, that the final resting state for the product of the reaction between uranyl and the acidic melt is the non-oxo uranium (V), and that this outcome is not in question.

1. Scan Rate and.Switching potential. Figures 4 \& 5 present the effects of changes in switching potential and scan rate on the electrochemistry of this system. These experiments focus only on the potential window from $2.3 \mathrm{~V}-1.4 \mathrm{~V}$. Three redox couples are present in this region for uranium $\left(\mathrm{UO}_{2}{ }^{2+/ 1+}, \mathrm{UO}^{4+/ 3+}, \mathrm{U}^{4+/ 3+}\right)$. Note that, as predicted, scans run under a faster scan rate show less electrochemical degradation of the uranium-oxo species to the non-oxo species than those run at slower scan rates. Further, if the direction of the scan is reversed prior to the second wave $\left(\mathrm{UO}_{2}{ }^{2+} / \mathrm{UO}_{2}{ }^{+}\right)$ much less degradation is observed. These observations are in line with our scheme that calls for the rapid oxygen transfer from the di-oxo uranium (V) species to the melt.

2. $\mathrm{UO}_{2}{ }^{2+}$ vs $\mathrm{UOCl}_{5 \text {. }}$ Based on our proposed scheme, the first intermediate formed would be the result of an acid/base reaction between the melt and the uranyl moiety resulting. in the transfer of an oxygen from the uranium to the melt. This would result in a uranium mono-oxo intermediate. The conclusion is supported by figures 6 which shows a comparison between the electrochemistry of $\mathrm{UO}_{2}{ }^{2+}$ and an authentic sample of $\mathrm{UOCl}_{5}{ }^{-}$. The $\mathrm{CV}$ of the authentic mono-oxo uranium species appears to be growing in with time from the starting uranyl.

\section{3. $\mathrm{UO}_{2}{ }^{2+} / \mathrm{U}(\mathrm{IV})-\mathrm{ECE}$ mechanism}

The ECE mechanism is of great importance in the study of coupled chemical reactions. In general, these reactions can be represented as:

$$
\mathrm{A}+\mathrm{e}-\Leftrightarrow \mathrm{B} \cdots \mathrm{B} \rightarrow \mathrm{C} \cdots \mathrm{C}+\mathrm{e}-\Leftrightarrow \mathrm{D}
$$

If the product $\mathrm{C}$ is more easily reduced than $\mathrm{A}$ then the reaction will proceed spontaneously to $\mathrm{D}$ following the first reduction. The theory of ECE mechanism was first elaborated by Nicholson and Shain (20) (21). If a system is coupled in this way, then at short times the principle current observed is related to the reduction of $A$ to $B$ by $n 1$ electrons, while at longer times (ie. slower sweep rates) the current represents the reduction of $A$ to $D$ by $n 1+n 2$ electrons. The Nicholson treatment has been applied to the first reduction wave seen in the cyclic voltammogram of uranyl. In figure 7 a plot of $\mathrm{Ipc} / \widehat{V}_{\mathrm{V}}$ vs $\log \mathrm{v}$ is reported ${ }^{1}$. The shape of this curve fits very well with that reported by

\footnotetext{
${ }^{1}$ Note: $\mathrm{Ipc}=2.69 \times 10^{5} \mathrm{n}^{3 / 2} \mathrm{AD}^{1 / 2} \mathrm{Cv}^{1 / 2}$
} 
Nicholson for the theoretical shape for an ECE mechanism. Further, a plot of Ipc vs $\sqrt{v}_{\mathrm{v}}$ (figure 7) shows two linear regions indicating two distinct scan rate dependent proccesses. At fast scan rates this plot indicates that a one electron process is involved. At slow scan rates it appears that the slope of the curve doubles, indicating a process having two coupled 1 electron transfers.

\section{B. Low Temperature Spectroscopv.}

A report that $\mathrm{EMIC} / \mathrm{AlCl}_{3}$ forms low temperature glasses in both acidic and basic melts prompted our investigations into the possible use of this solvent system for luminescence studies (22). Our initial investigations focused on the much studied $\mathrm{UO}_{2} \mathrm{Cl}_{4}{ }^{2-}$ ion. We were able to prepare glasses of moderate optical clarity in $1 \mathrm{~cm}$ cuvettes at liquid nitrogen temperature. Under these conditions we observed highly resolved uranyl luminescenece, remarkably similar to the emission reported from low temperature single crystals of various $\mathrm{UO}_{2} \mathrm{Cl}_{4}^{-2}$ salts (23) or $\mathrm{UO}_{2} \mathrm{Cl}_{4}^{-2}$ doped into cubic crystals (24). The electronic transition is electric dipole forbidden and is vibronically enabled through coupling to ungerade vibrations. We observed linewidths that are significantly wider than those reported for single crystals at $77 \mathrm{~K}^{24 \mathrm{~d}}$, indicating that inhomogeneous line broadening may be important in our solvent system. We deconvolved the emission spectrum (figure 8) to obtain ground state vibrational frequencies. The values that we obtained are in good agreement with the low temperature crystal data as shown in the Table below.

\begin{tabular}{|c|c|c|c|c|c|}
\hline \multicolumn{6}{|c|}{ VIBRATIOAL FREQUENCIES (cm ${ }^{-1}$ ) DERIVED FROM EMISSION } \\
STUDIES \\
\hline
\end{tabular}

a) Unrestricted Gaussian fits, using unweighted averages for vibrational intervals

b) Restricted Gaussian fits

c) Room temperature Raman

We measured an emission lifetime of nearly 2 milliseconds, about the same as in low temperature crystals. This indicates that energy transfer processes involving the solvent are relatively inefficient and provides encouragement for further luminescence studies of other actinide species in this medium.

\section{Plutonium Studies.}

As mentioned in the introduction, one of the drivers for our work is the goal of developing new process schemes for the purification of actinides and actinide waste 
forms. In figure 9 we present the cyclic voltammograms of $\mathrm{PuCl}_{3}$ and $\mathrm{Cs}_{2} \mathrm{PuCl}_{6}$ in a basic $\mathrm{AlCl}_{3} / \mathrm{EMIC}$ ionic liquid. Clearly, we are observing the psuedo-reversible $\mathrm{Pu}^{4+/ 3+}$ couple $\left(\mathrm{E}^{\circ}=0.37 \mathrm{~V}\right)$. In the $\mathrm{PuCl}_{3} \mathrm{CV}$ we also observe a second irreversible wave at $\mathrm{Ep}=$ $0.35 \mathrm{~V}$. We believed that this peak could be the result of an incipent Pu-oxo species in out $\mathrm{PuCl}_{3}$.

$\mathrm{PuO}_{2} \mathrm{Clx}$ was synthesized by the bulk electrolysis of $\mathrm{PuCl}_{3}$ in $1 \mathrm{M} \mathrm{HCl}$ and have confirmed its characterization through UV-Vis spectroscopy in both $\mathrm{HCl}$ and $\mathrm{HNO}_{3}$. The cyclic voltammogram of this species in basic $\mathrm{AlCl}_{3} / \mathrm{EMIC}$ is shown in figure 10. Notice that this voltammogram looks very much like that shown for the $\mathrm{PuCl}_{3}$ in the basic melt. On repeated scans the irreversible wave disappears (Figure 11) and there is a growth in the first wave. The growth in the first wave does not appear to be concommitant with the loss of the more anodic wave and is attributed to a kinetically slow ECE mechanism. We have also examined the electrochemistry of $\mathrm{PuO}_{2} \mathrm{Cl}_{2}$ in an acidic $\mathrm{AlCl}_{3} / \mathrm{EMIC}$ RTIL. The cyclic voltammetry of this system is shown in figure 12. This result is similar to that obtained for uranyl in this melt. The plutonyl quickly looses its oxygens to the melt and forms an insoluble precipitate, presumably $\mathrm{Pu}$ (IV).

In figure 13 we show all of the possible pathways for the chemical and electrochemical reactions of $\mathrm{PuO}_{2} \mathrm{Cl}_{2}$ in the basic melt. Although our data to date is rather scant we have been able to rule out several of the available pathways, as shown in the figure. Admittedly, this scheme must be approached as speculative given out current data set. However, we can make a few statements in support. Our current understanding of the chemistry of $\mathrm{Pu}$ in the $\mathrm{AlCl}$ /EMIC system and the basis for our proposed mechanism are summarized below:

1) The scheme presents all of the possible pathways for the reaction of $\mathrm{PuO}_{2}{ }^{2+}$ in the melt.

2) We have confirmed by UV-Vis that that starting product, at least in aqueous media, is $\mathrm{PUO}_{2}{ }^{2+}$

3) From our voltammetry on the non-oxo $\mathrm{Pu}^{3+/ 4+}$ couple, we can rule out any stable nonoxo products above the +4 oxidation state

4) We have shown experimentally that $\mathrm{PuO}_{2}$ has negligible solubility in this melt.

5) Both Ipvs $v^{1 / 2}$ and Chronocoulometry suggests that there are at least two processes underway at $\mathrm{E}=.35 \mathrm{~V}$, suggesting the presence of multiple species at this potential.

6) Neither Pu3+ or Pu4+ have any solubility in acidic AlCl3/EMIC

7) $\mathrm{PuO}_{2} \mathrm{Cl}_{2}$ has an irreversible redox couple in the acidic system and all activity dissappears within several minutes with the formation of an insoluble precipitate.

1. Schoebrechts, J.P.; Gilbert, B., Inorg. Chem., 24, 2105, (1985).

2. Dewaele, R.; Heerman, L.; D'olieslager, W. J. Electroanal. Chem. Interfac. Electrochem. 142, 137, (1982).

3. Dewaele, R. Heerman, L.; D'Olieslager, W. J. Less Common Met., 122, 319, (1986).

4. Anderson, C.J.; Deakin, M.R.; Choppin, G.R.; D'Olieslager, W.D.; Heerman, L.; Pruett, D.J.; Inorg. Chem., 30, 4013, (1990). 
5. Selbin, J.; Ortego, J.D. Reviews, 69, 657, (1969).

6. Wenz, D.A.; Adams, M.D.; Steunenberg, R.K. Inorg, Chem, 976, (1968).

7. Meuris, F.; Heerman, L.; D'Olieslager, W.; J. Electrochem. Soc., 127, 1294, (1980).

8. Anderson, C.J.; Deakin, M.R.; Choppin, G.R.; D'Olieslager, W.D.; Heerman, L.; Pruett, D.J. Inorg. Chem., 1991, 30, 4013-4016.

9. Schoebrechts, J.P.; Gilbert, B. Inorg. Chem. 1985, 24, 2105-2110.

10. Hitchcock, P.B.; Mohammed, T.J.; Seddon, K.R.; Zora, J.A.; Hussey, C.L.; Ward, E.H. Inorg, Chim. Acta 1986, 113, L25.

11. Heerman, L.; DeWaele, R.; D’Olieslager, W.J. Electroanal. Chem. Intrerfacial Electrochem. 1985, 193, 289-294.

12. Hitchcock, P.B.; Mohammed, T.J.; Seddon, K.R.; Zora, J.A.; Hussey, C.L.; Ward, E.H. Inorg, Chim. Acta 1986, 113, L25

13. Fields, M.; Hutson, G.V.; Seddon, K.R.; Gordon, C.M. World Patent, WO 98/06106, 1998.

14. British Nuclear Fuels PLC, WO1999GB0000246 1999

15. Anderson, J.C.; Pruett, D.J.; Choppin, G.R. Costa, D.A.; Smith, W.H. Radiochim. Acta. 84, 31-36 (1999).

16. Costa, D.A.; Smith, W. H. Proc. Eleventh Int. Symp. on Molten Salts 1998.

17. Plutonium Handbook, Volumes 1 and 2, O.J. Wick, Editor, American Nuclear Society, 1980.

18. Rabideau, S.W.; Cowan, H.D. J. Am. Chem. Soc., 77, 6145, 1955.

19. Smith, G.P.; Dworkin, A.S.; Pagni, R.M.; Zingg, S.P. J. Am.Chem.Soc. 111, 1989, 525.

20. Nicholson,R.S.; Shain, I. Anal.Chem.,36,706, 1964.

21. Alberts, G.E.; Shain, I. Anal. Chem. 35, 1963, 1859-1866.

22. Fannin, D. A. Floriani, L. A. King, J. S. Landers, B. J. Piersma, D. J. Stech, R. L. Vaughn, J. S. Wilkes, and J. L. Williams, J. Phys. Chem. 1984, 88, 2614-2621

23. a) $\mathrm{Cs}_{2} \mathrm{UO}_{2} \mathrm{Cl}_{4}$ : C. D. Flint and P. A. Tanner, J. Chem. Soc., Faraday Trans. II, 1978, 74, 2210-2217. b) $\left(\mathrm{Et}_{3} \mathrm{NH}\right)_{2} \mathrm{UO}_{2} \mathrm{Cl}_{4}$ : C. D. Flint and P. A. Tanner, J. Chem. Soc., Faraday Trans. II, 1979, 75, 11681178.

c) $\left(\mathrm{Me}_{4} \mathrm{~N}\right)_{2} \mathrm{UO}_{2} \mathrm{Cl}_{4}$ : C. D. Flint and P. A. Tanner, J. Chem. Soc., Faraday Trans. II, 1981, 77, $1865-$ 1878.

d)(Imidazolium) ${ }_{2} \mathrm{UO}_{2} \mathrm{Cl}_{4}$ and (2-methylimidazolium) ${ }_{2} \mathrm{UO}_{2} \mathrm{Cl}_{4}: \mathrm{H}$. G. Brittain, D. L. Perry, and L. Tsao, Spectrochimica Acta, 1984, 40A, 651-655.

24. C. D. Flint and P. A. Tanner, J. Luminescence, 1979, 18/19, 69-72.

b)D. H. Metcalf, S. Dai, G. D. Del Cul, and L. M. Toth, Inorg. Chem., 1995, 34, 5573-5577. 


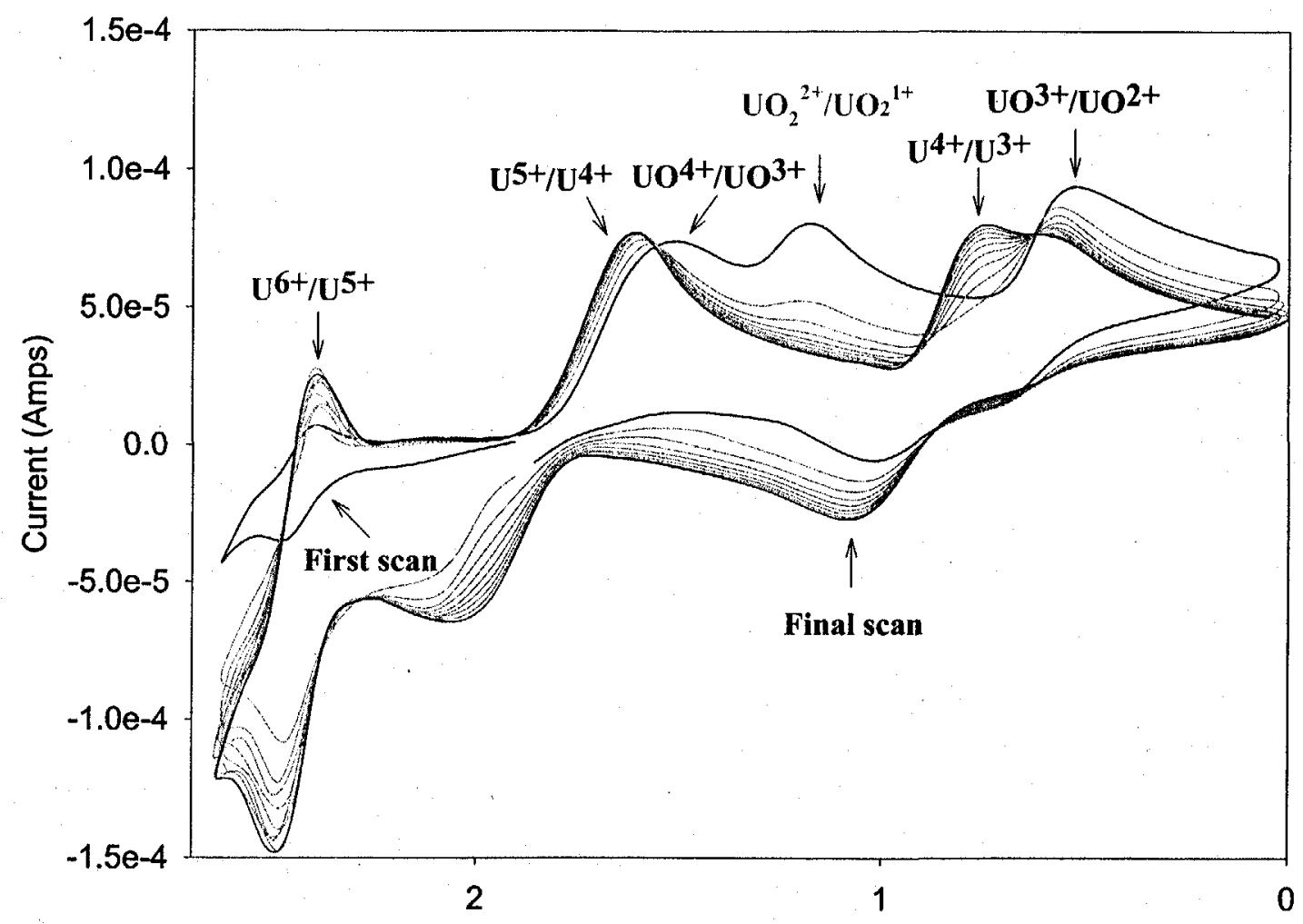

Figure 2. Multicyclic and single scan voltammograms of uranyl chloride $\left(\mathrm{UO}_{2} \mathrm{Cl}_{\mathrm{x}}\right)$ in a 55/45 acidic aluminium chloride/1-ethyl-3-methyl imidazolium chloride RTIL. 


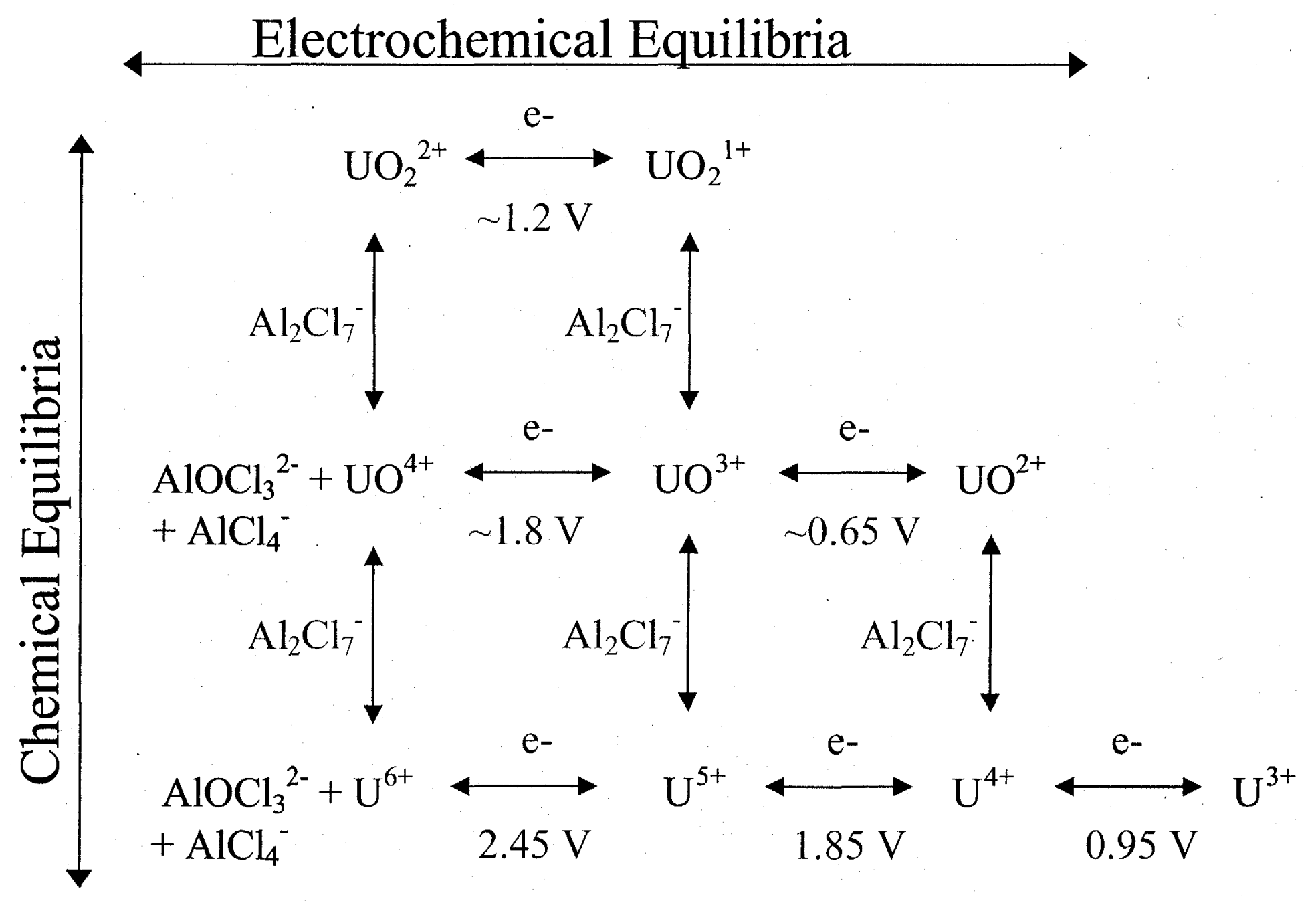

Figure 3. Overall scheme for the reaction of uranyl chloride in acidic RTIL. 


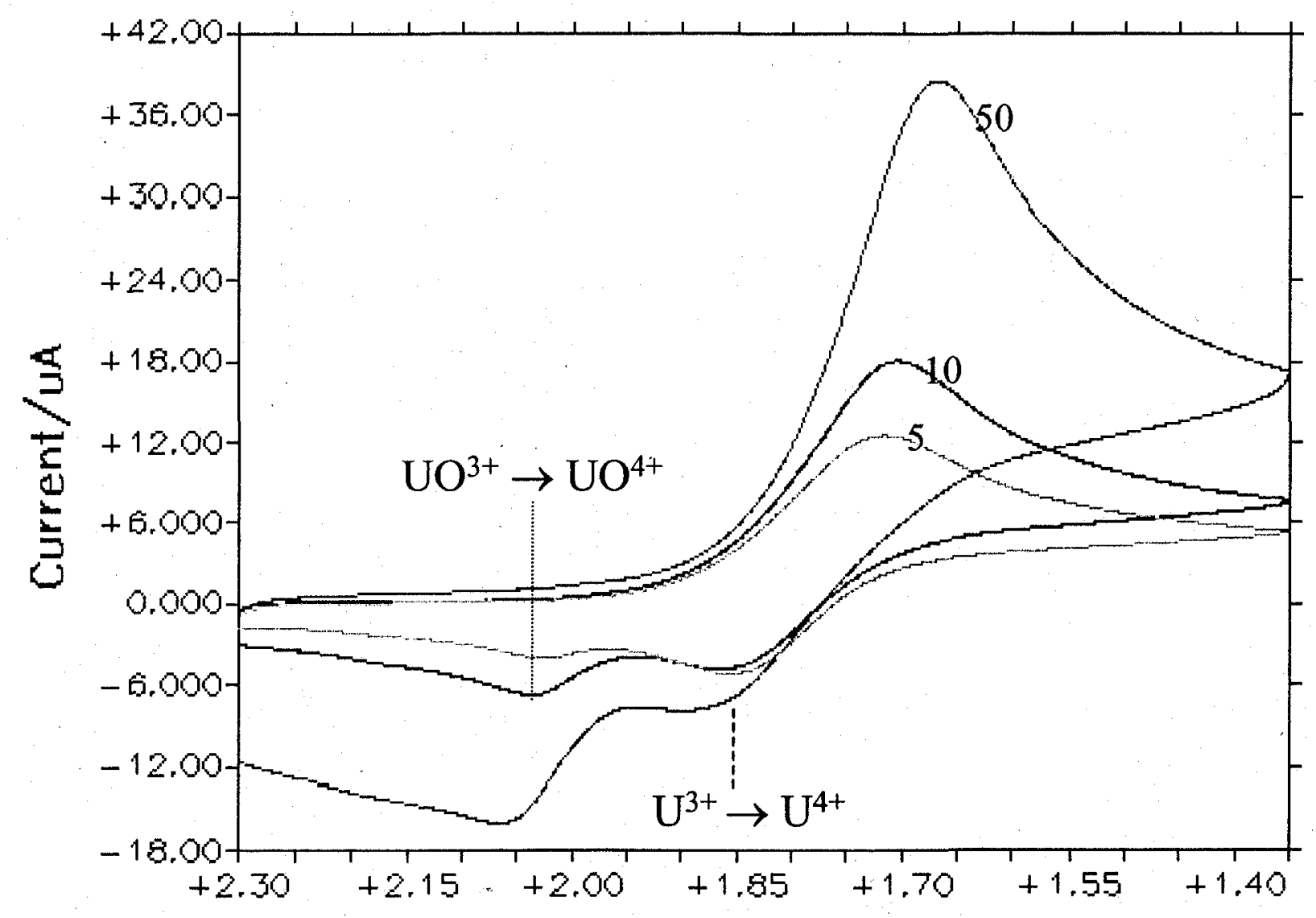

Figure 4. Effect of scan rate on the voltammogram of $\mathrm{UO}_{2}{ }^{2+}$

The scan rates shown are 5,10 and $50 \mathrm{mV} / \mathrm{s}$. 

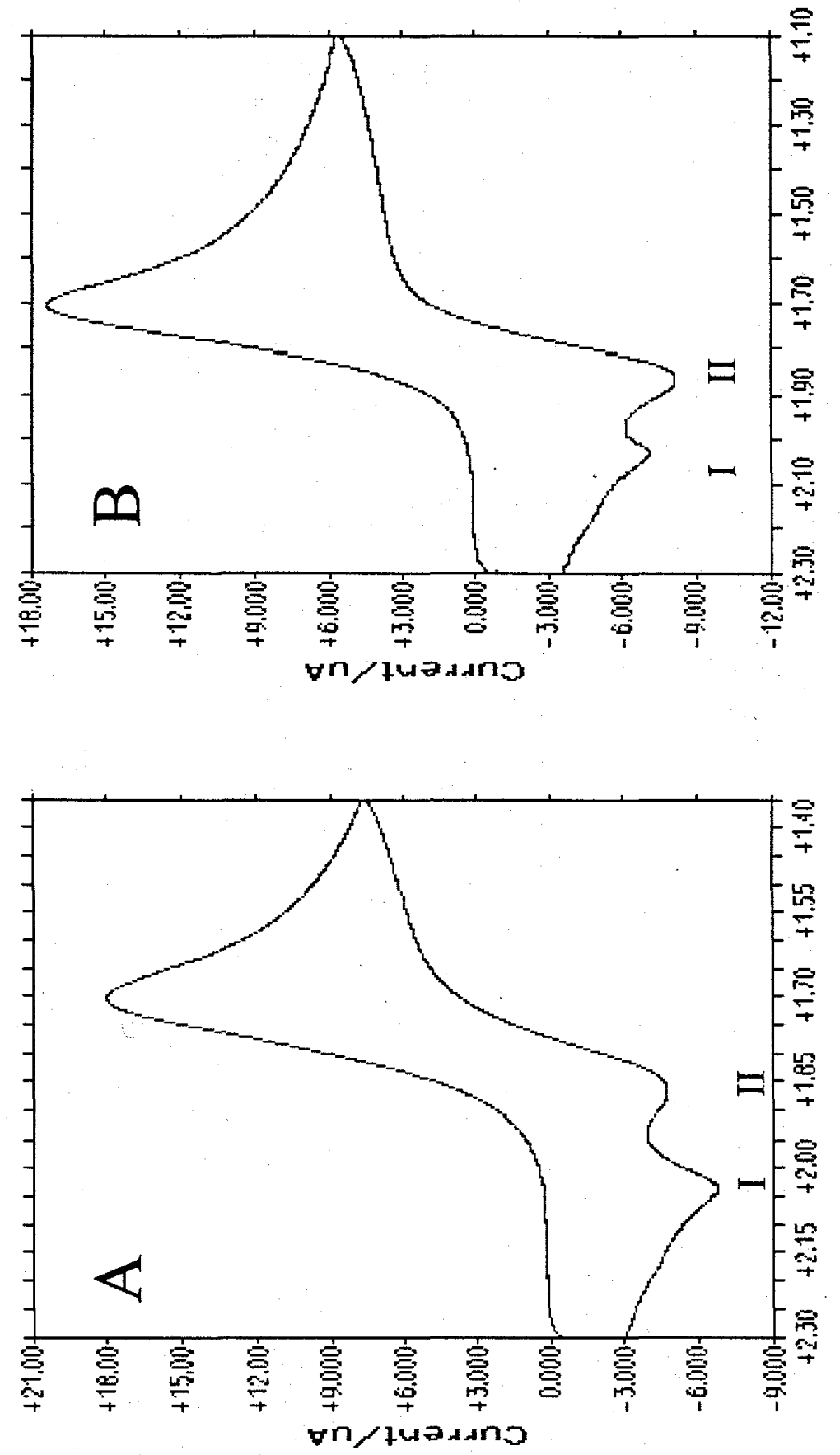

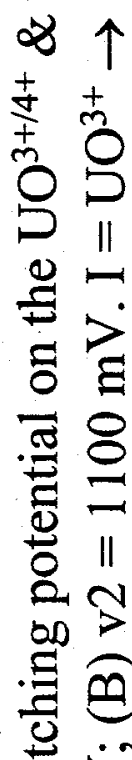

-

ㅇ

\&

$\infty_{11}$

롤

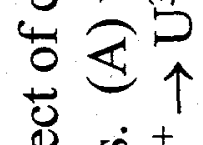

速焉吉

i

党志吉吉 


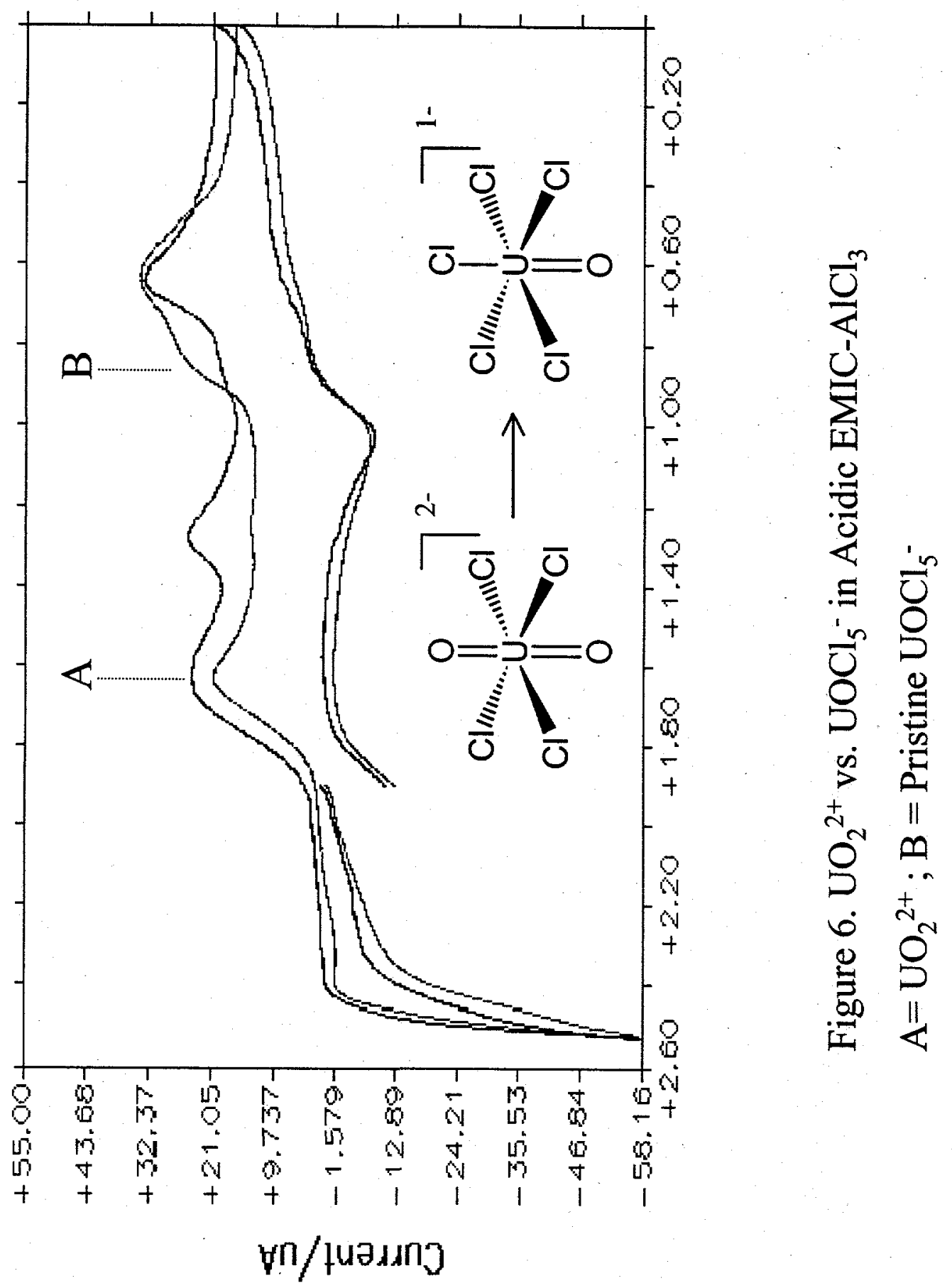



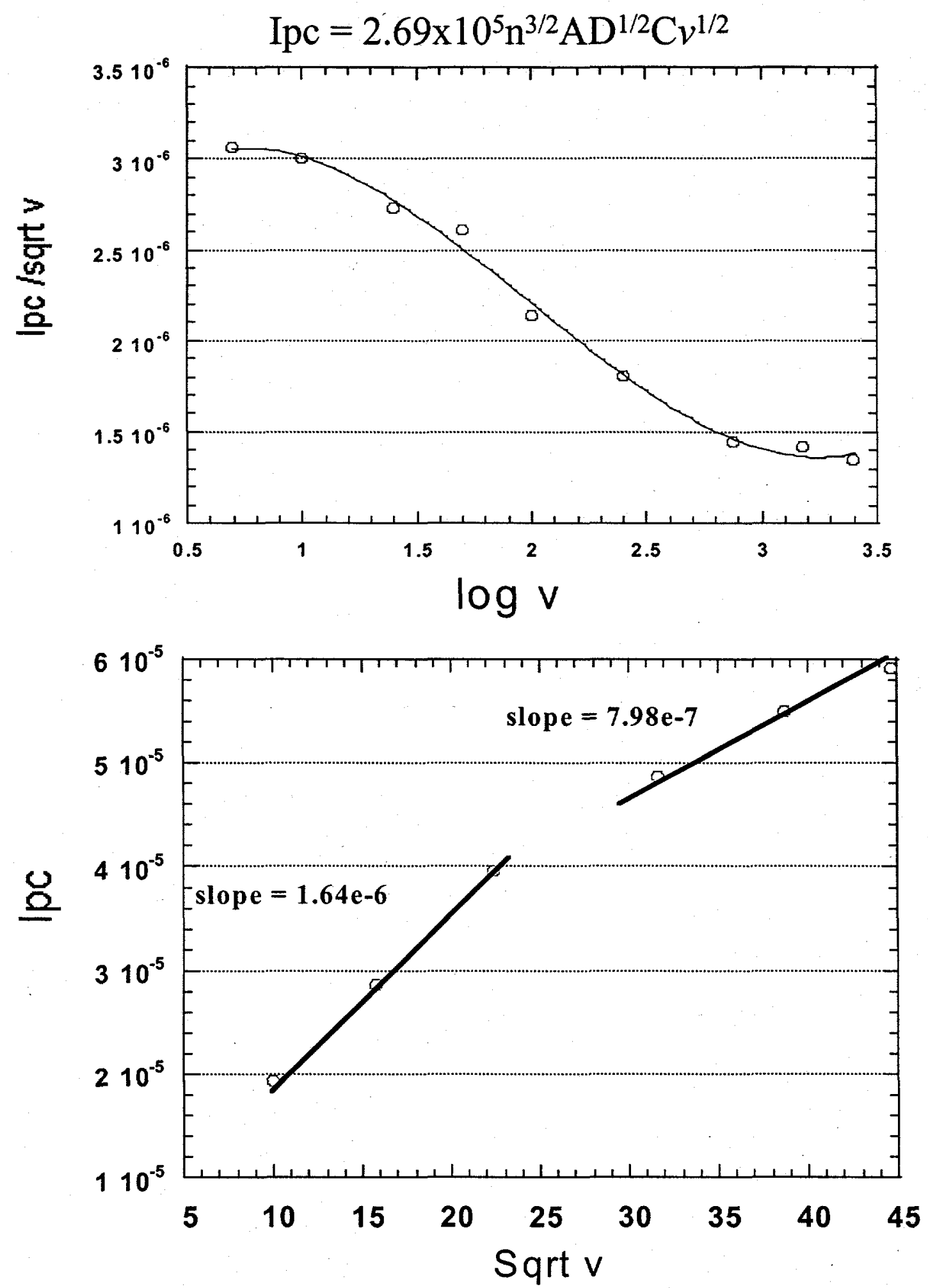

Figure 7. Nicholson treatment of ECE mechanism 


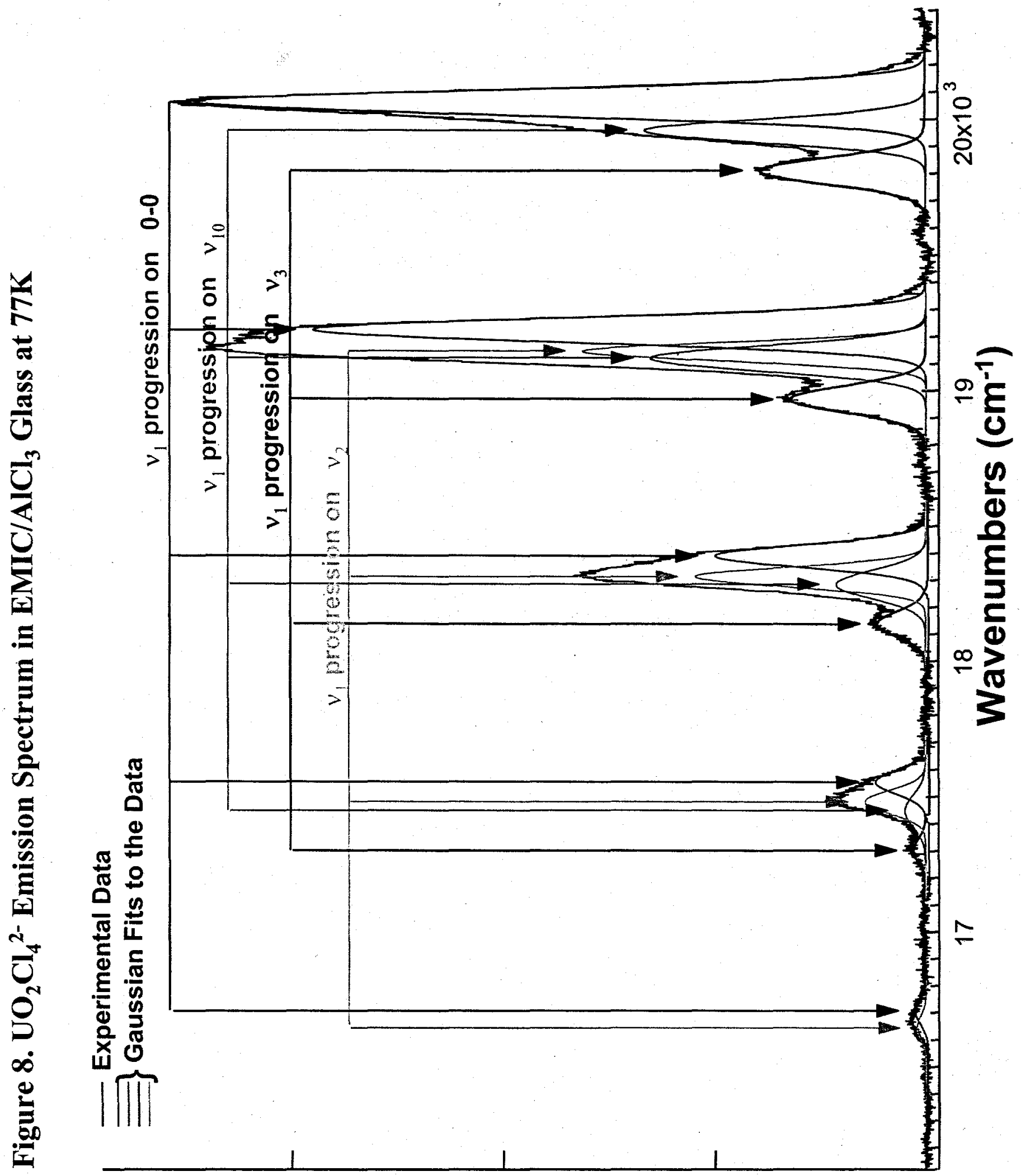

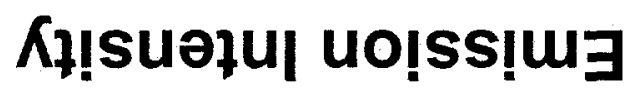




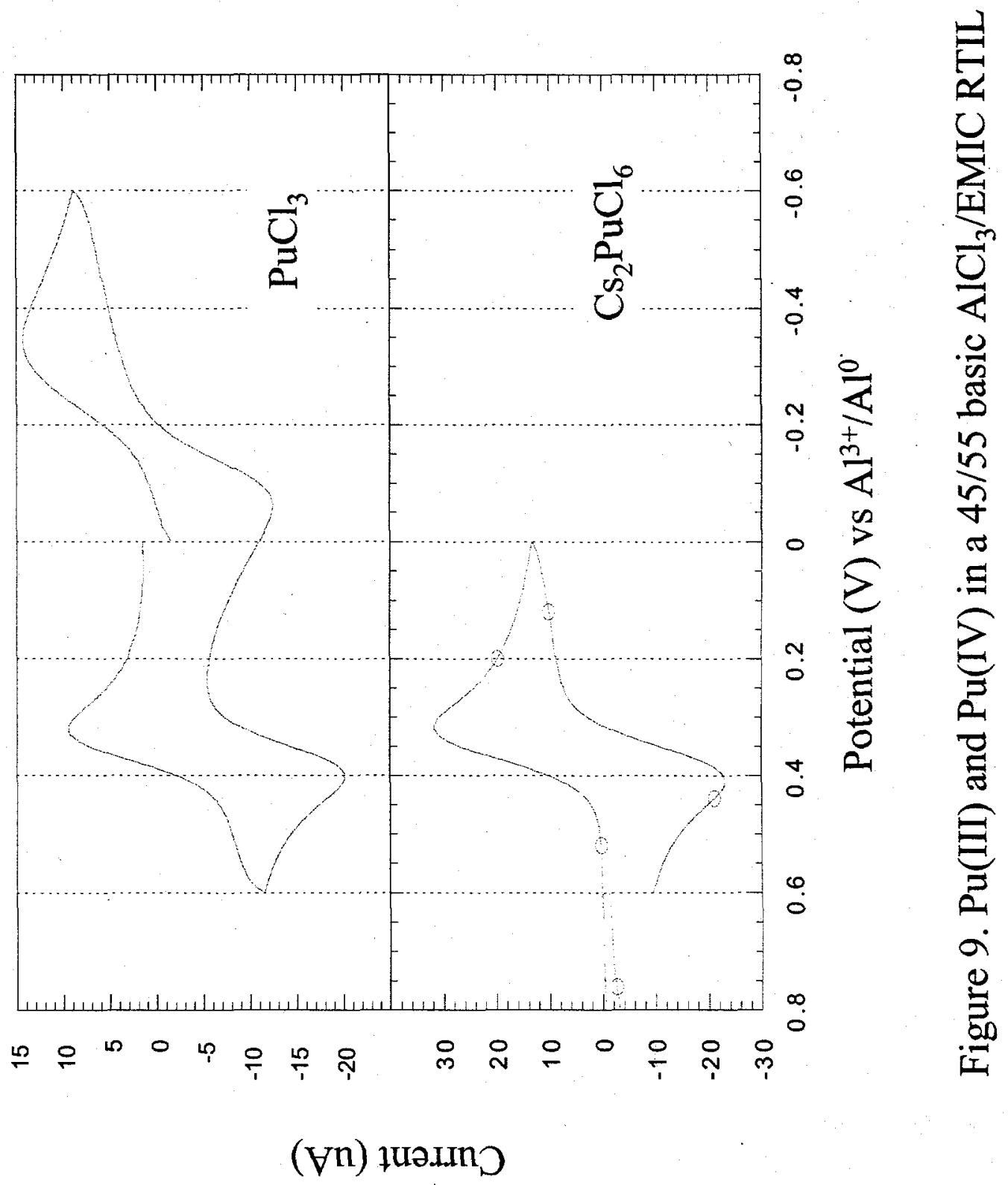




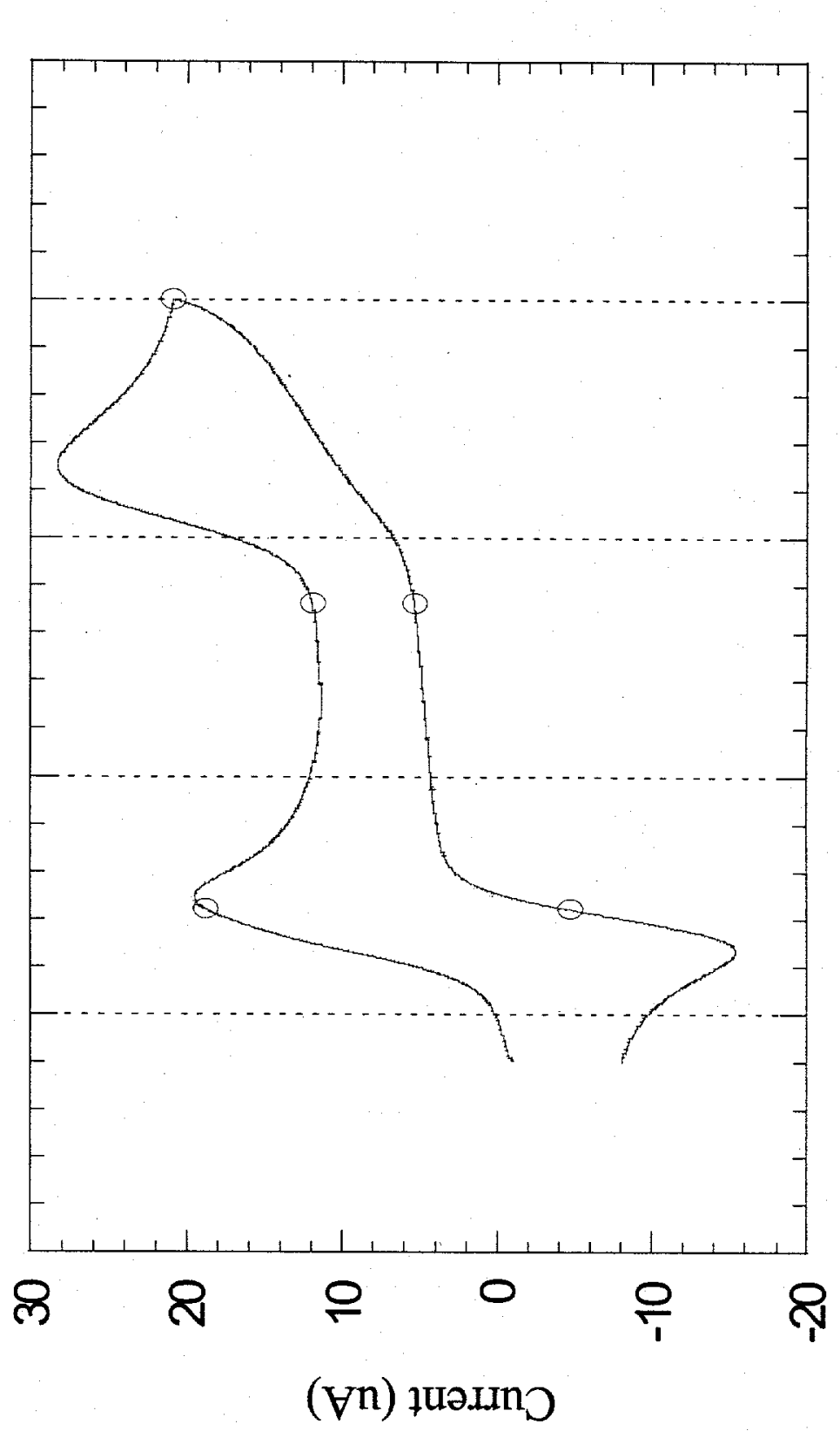

$\frac{8}{1}$
8
$\frac{8}{1}$
8

$\frac{0}{U}$

$\frac{n}{n}$

$\frac{0}{\frac{1}{4}}$

0

$>$

㿣

8

.



㿟

0

8

$\frac{0}{0}$ 

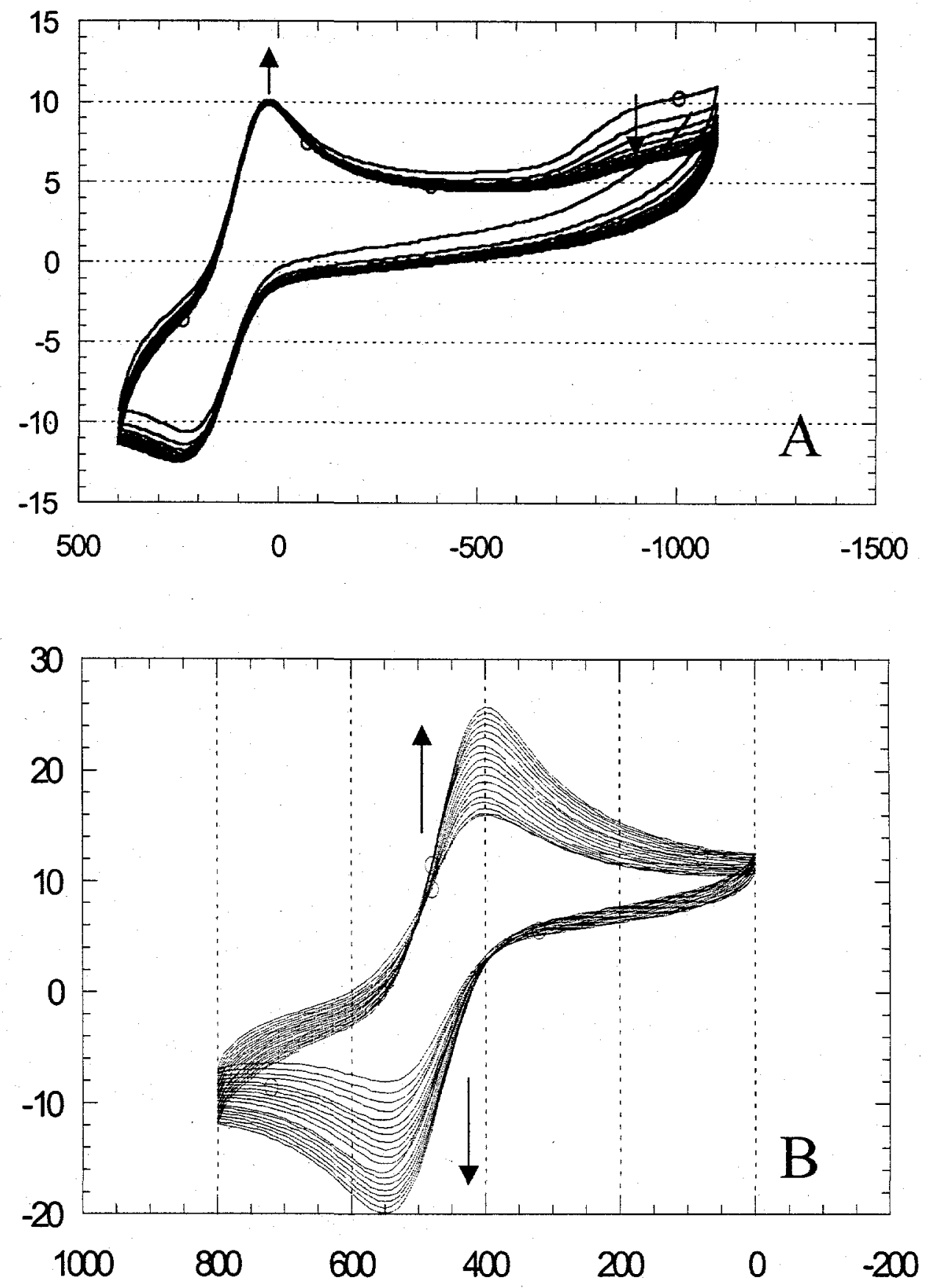

Figure 11. Cyclic voltammetry of $\mathrm{PuO}_{2}{ }^{2+}$ in basic $\mathrm{ALCl}_{3} / \mathrm{EMIC}$ RTIL. (A) Full scan (B) Highlight 1st wave. 


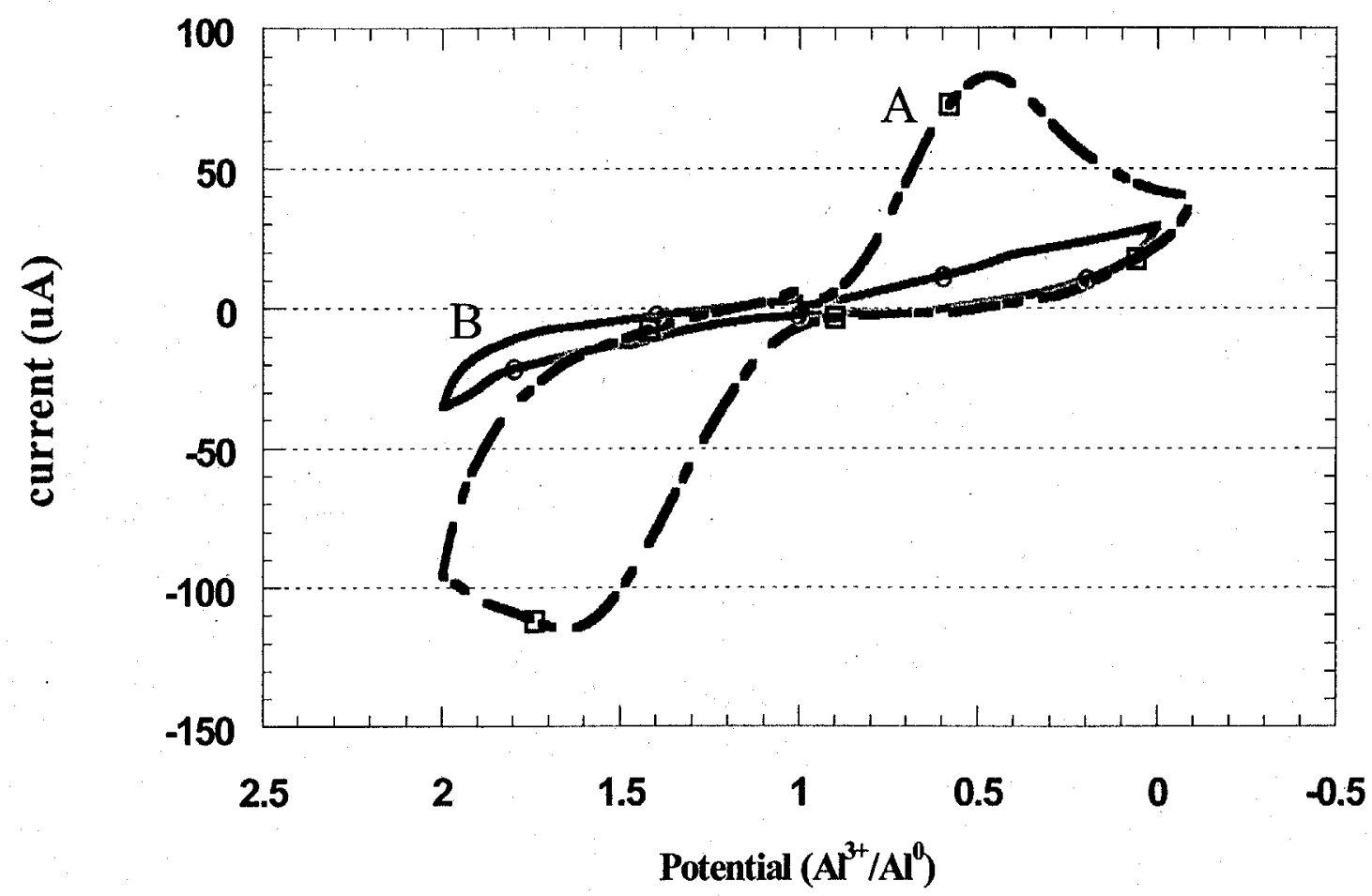

Figure 12. Cyclic voltammetry of $\mathrm{PuO}_{2}{ }^{2+}$ in 55/45 acidic $\mathrm{AlCl}_{3} / \mathrm{EMIC}^{\mathrm{RTIL}}$.

(A) $\mathrm{t}=0$ min. (B) $\mathrm{t}=5 \mathrm{~min}$. 


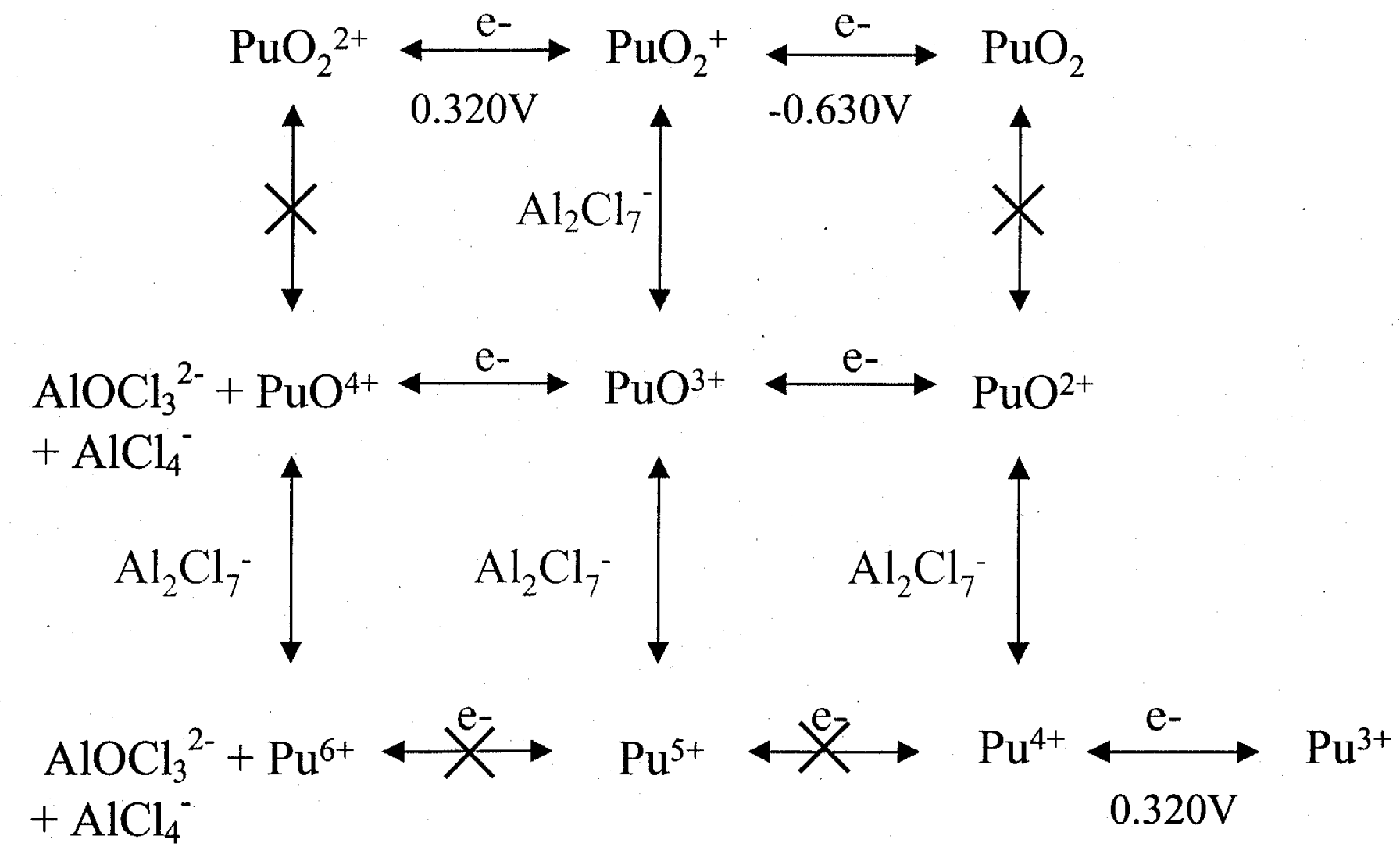

Figure 13. Possible reaction pathways for $\mathrm{PuO}_{2}{ }^{2+}$ in $\mathrm{AlCl}_{3} / \mathrm{EMIC}$ RTIL 


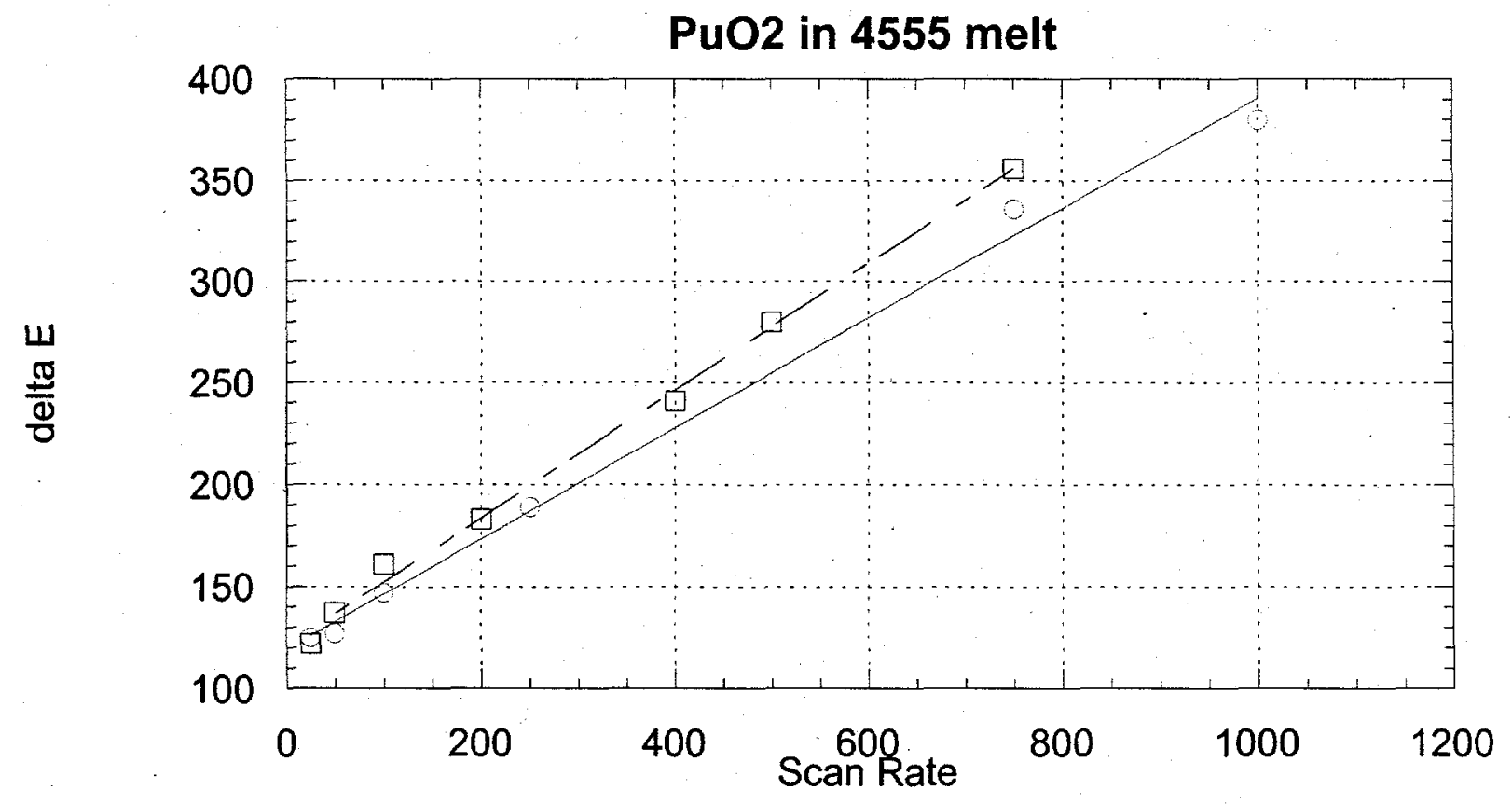




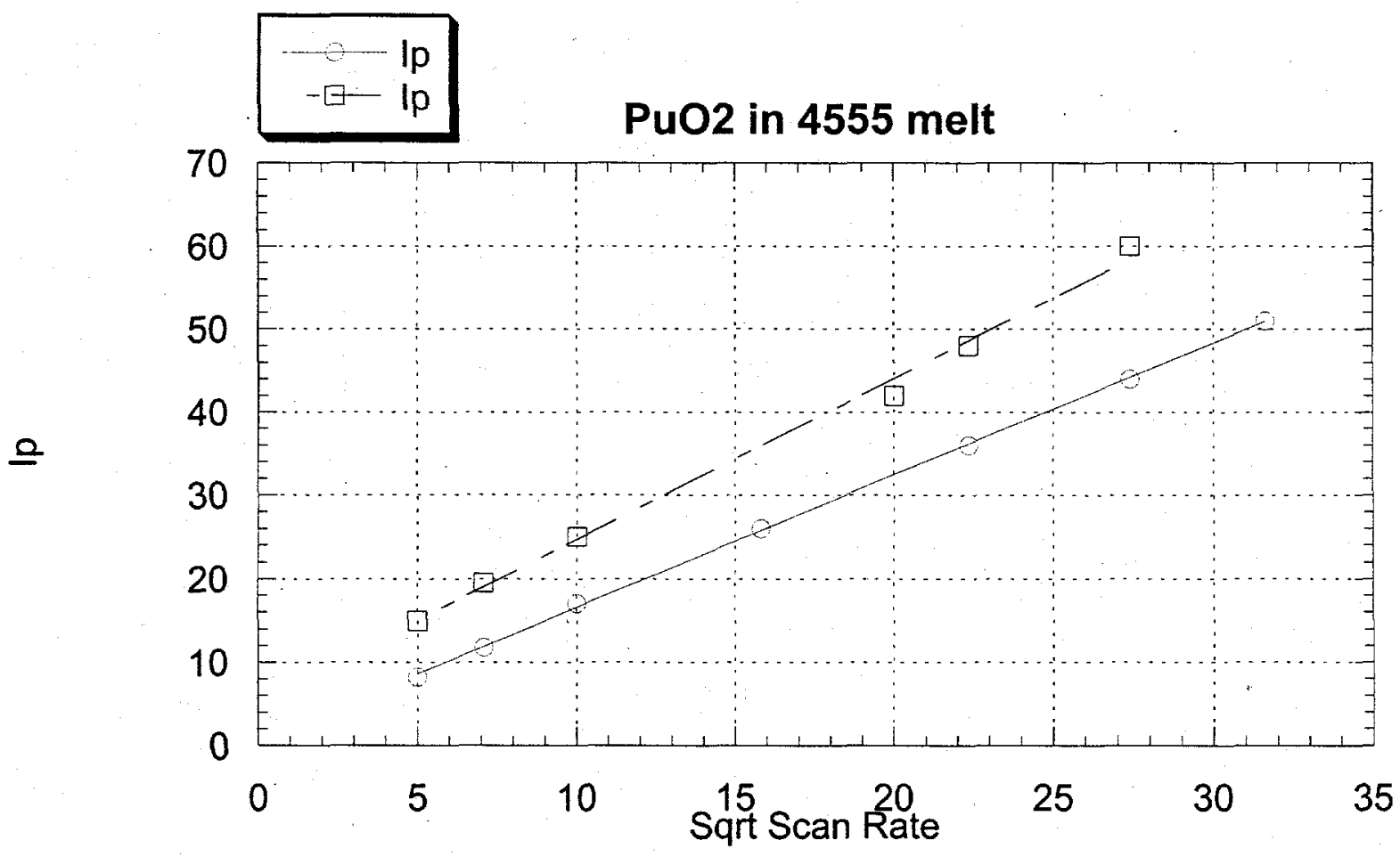


Model 270/250 Research Electrochemistry Software, v. 4.30

Filename: d: \pu \echem $\backslash 4555011$

Pstat: M273A[96] Ver 202

SWV SQUARE WAVE VOLTAMMETRY

Date Run: 10-04-99 Time Run: 15:43:49

$P T$ PASS CP PASS VS. R

IP 0.680 vs. R ET $5 \mathrm{~S}$

SI $1.000 E-02$ NC 10

RU 1.150E+03

RT HIGH STABILITY

AR $1.000 E+00$

FR 60.00

$\mathrm{PH} 0.025$

AU NO

File Status: NORMAL

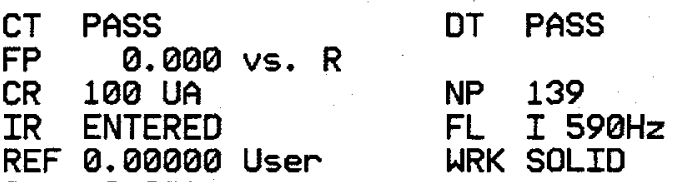

\section{1}

Square wave voltammetry of Puoz2+

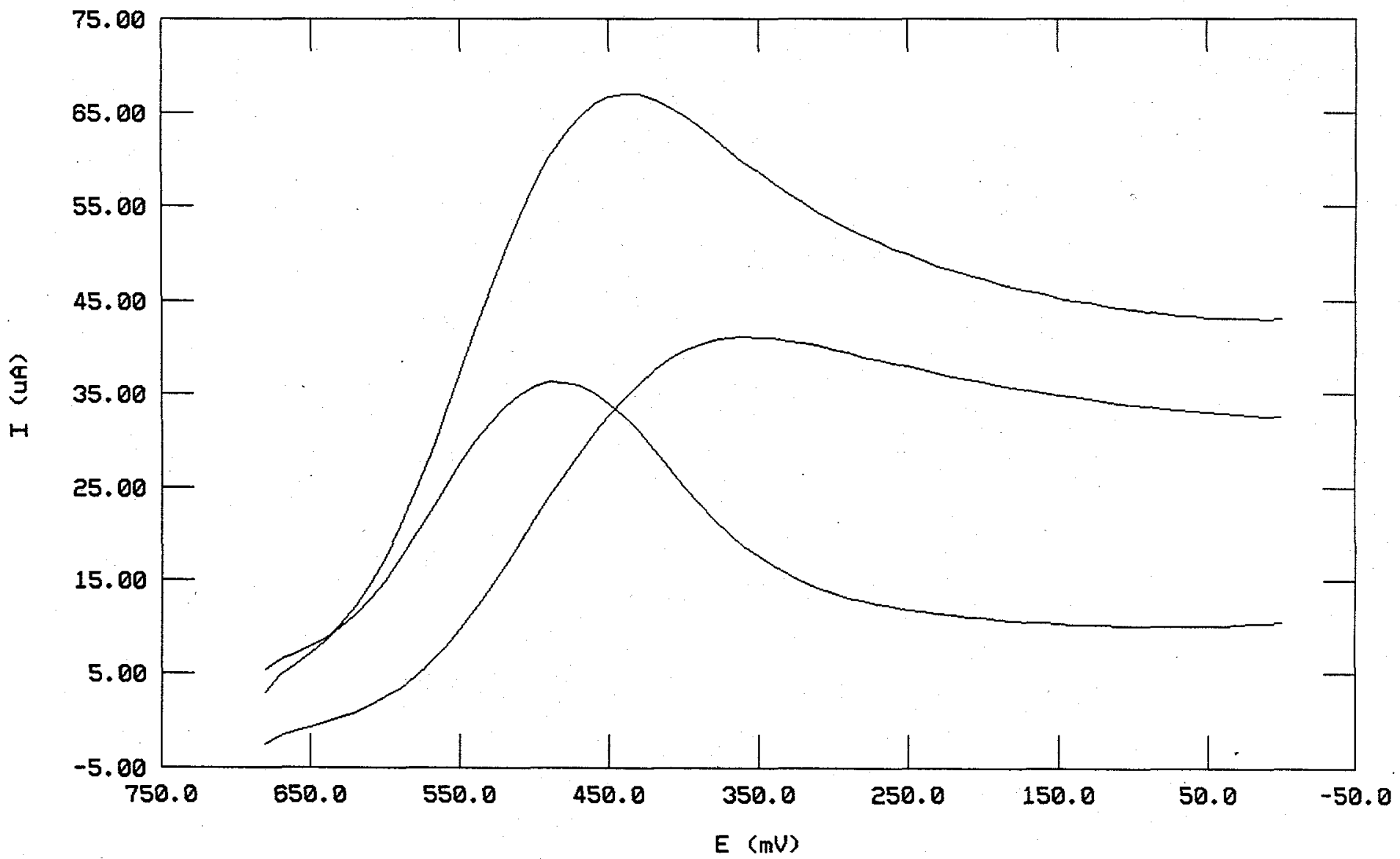


Model 270/250 Research Electrochemistry Software, V. 4.30 Filename:

Pstat: M273A[96] Ver 202

NPU NORMAL PULSE VOLTAMMETRY

File Status: EDITED Date Run: 10-06-99 Time Run: 11:47:23

PT PASS CP PASS VS. R

IP 0.680 vs. R ET 55

SI $4.000 \mathrm{E}-03$

NP 892

PW 5.000E-02

AR $1.000 E+00$

SR $4.000 \mathrm{E}-02$

RU 8.600E+02

REF 0.00000 User

AU . NO

CT PASS

FP -1.100 vs. R

ST 1.000E-01

IR ENTERED

WRK SOLID

\section{DT PASS}

CR 100 UA

FL NONE

OC 0.448

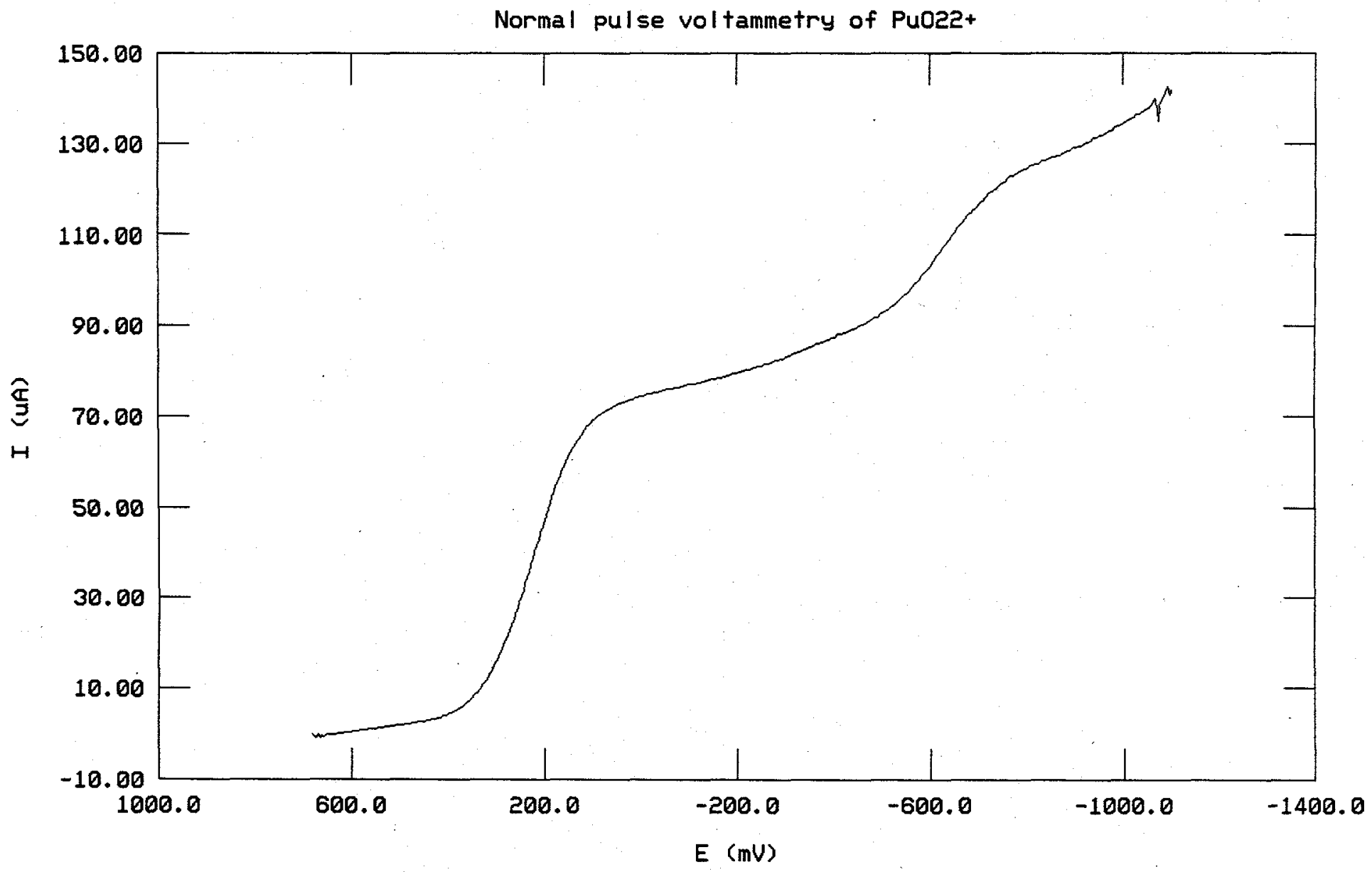


Note to reviewer:

The following overheads may be included in the talk along with those figures specifically included in the paper. 


\section{Time Evolved Absorption Spectra of $\mathrm{UO}_{2} \mathrm{Cl}_{2}$ in Acidic EMIC/AICl${ }_{3}$}
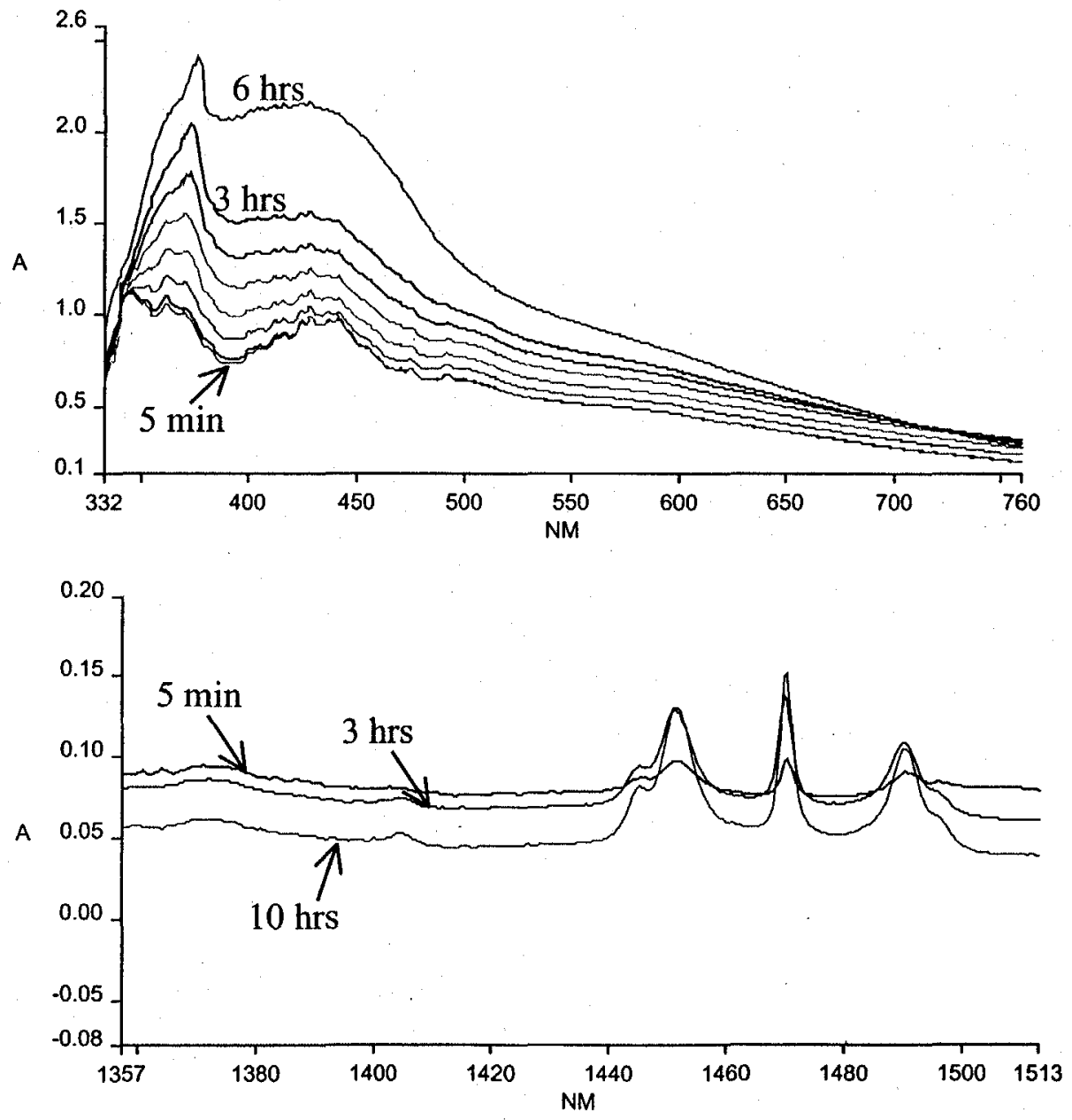


\section{Relative Uranium Potentials}

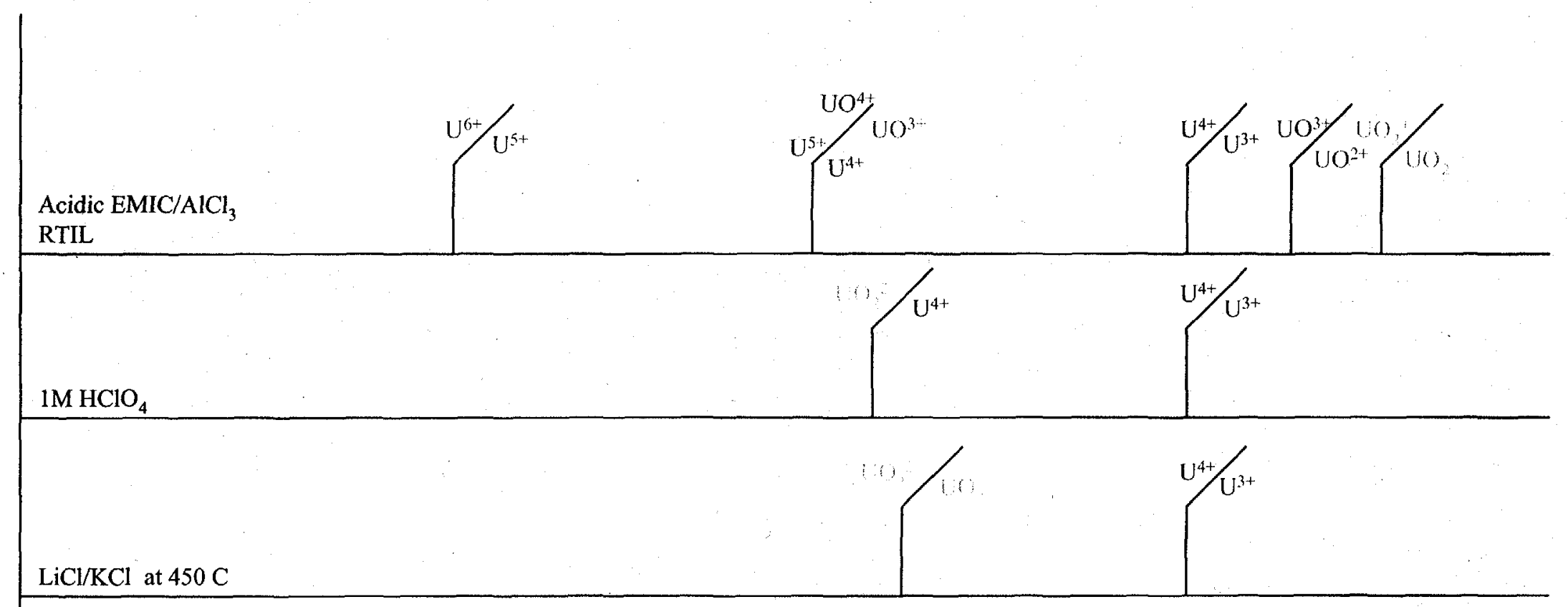

$1 \mathrm{M} \mathrm{HClO}_{4}$
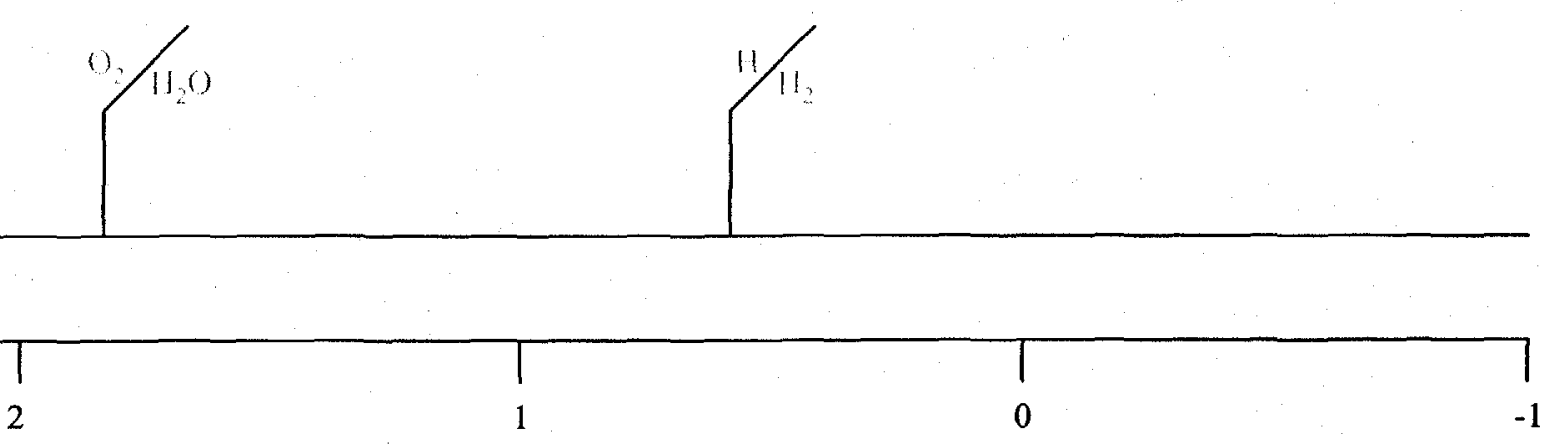

Potential vs. $\mathrm{U}^{4+} / \mathrm{U}^{3+}$ 


\section{Vibrational Modes of $\mathrm{UO}_{2} \mathrm{Cl}_{4}{ }^{2-}\left(\mathrm{D}_{4 \mathrm{~h}}\right)$}

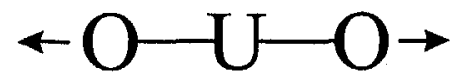

$\because 1$,

$831 \mathrm{~cm}^{-1}$

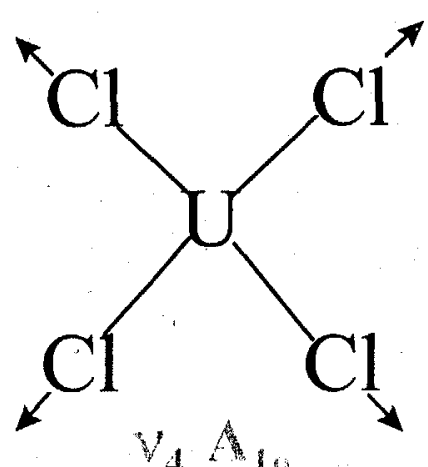

$264 \mathrm{~cm}^{-1}$

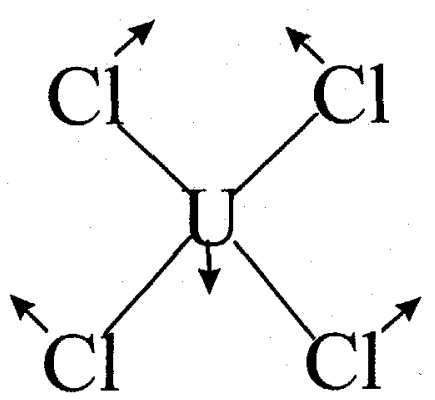

$v_{8} E_{u}$ $112 \mathrm{~cm}^{-1}$

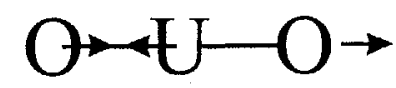

$v_{2} A_{2 u}$

$916 \mathrm{~cm}^{-1}$
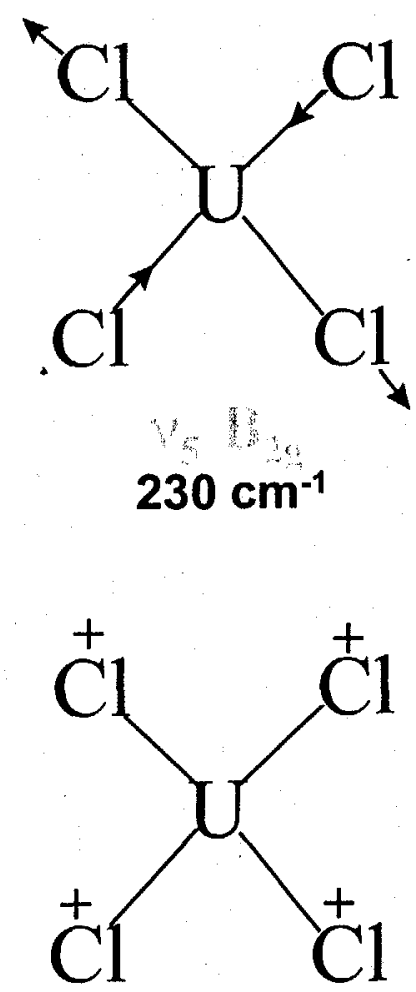

$v_{9} \cdot A_{2 u}$
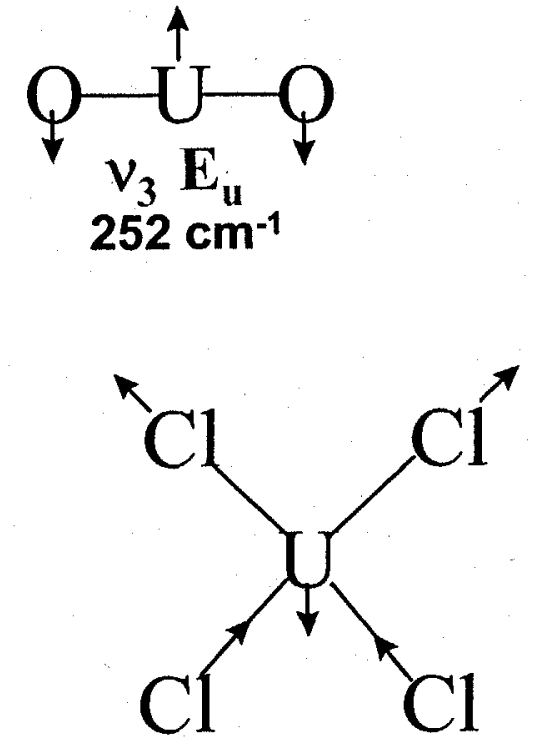

$$
\underset{238}{v_{6}} \underset{\mathrm{cm}^{-1}}{\mathrm{E}_{\mathrm{u}}}
$$

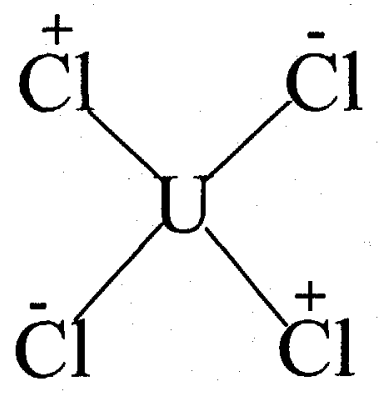

$$
v_{10} \mathrm{Bm}_{1 \mathrm{u}} \mathrm{u}
$$

Jonn Raman active red $=I R$ active black=inactive
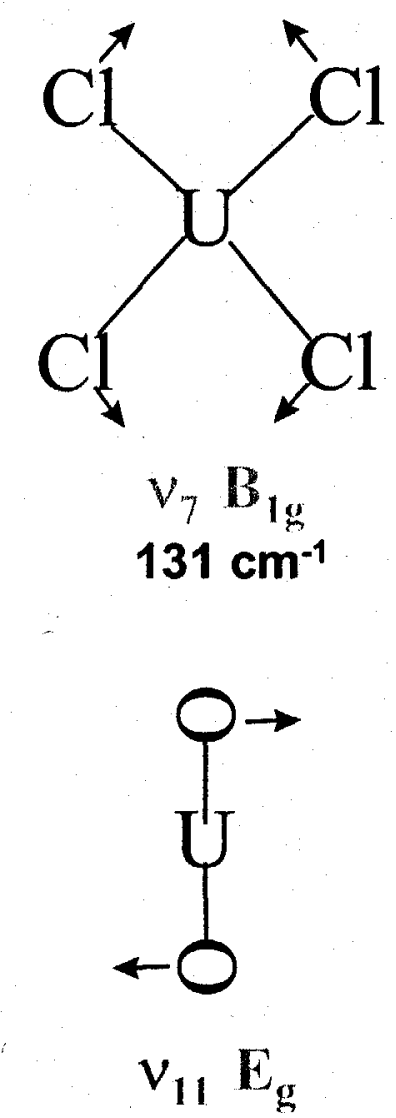
$200 \mathrm{~cm}^{-1}$

** Vibrational frequencies for low temperature crystalline $\mathrm{Cs}_{2} \mathrm{UO}_{2} \mathrm{Cl}_{4}$ : R. G. Denning, et al., Mol. Phys., 1976, 32, 419-442. 


\section{One - vs Two-Photon Absorption: complementary techniques}

- Electronic transitions are electric-dipole forbidden in OPA

- In OPA, the vibrational structure arises from both ungerade and gerade modes
- Electronic transitions are electric-dipole allowed in TPA

- In TPA, the vibrational structure arises from gerade modes 


\section{Two Photon Spectroscopy of $\mathrm{UO}_{2} \mathrm{Cl}_{2}$ at $77 \mathrm{~K}$}

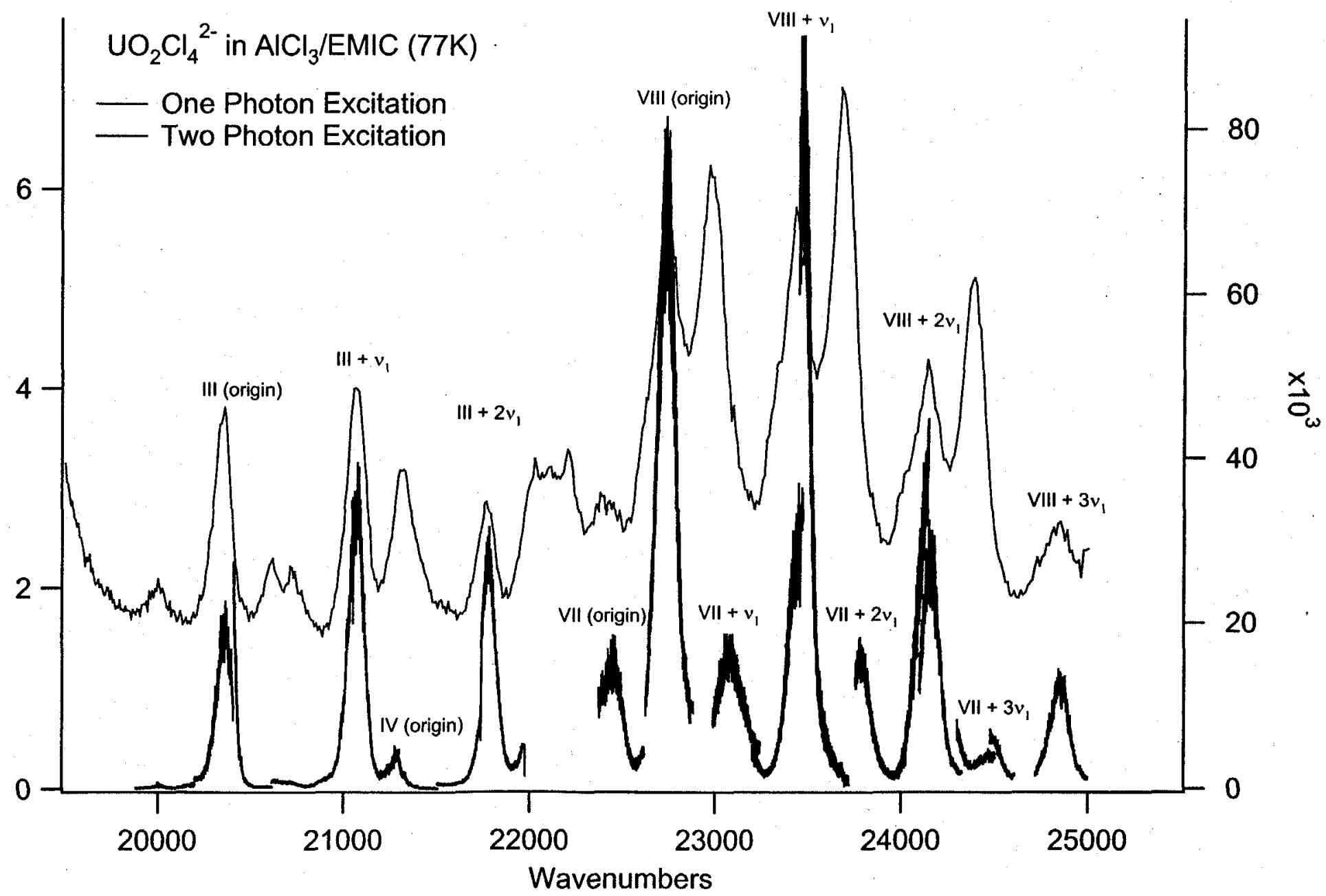




\section{Fit of Uranium EXAFS Scattering for EMIC Melts}

U(IV): Single chlorine shell

at $2.60 \AA, n=7.05$
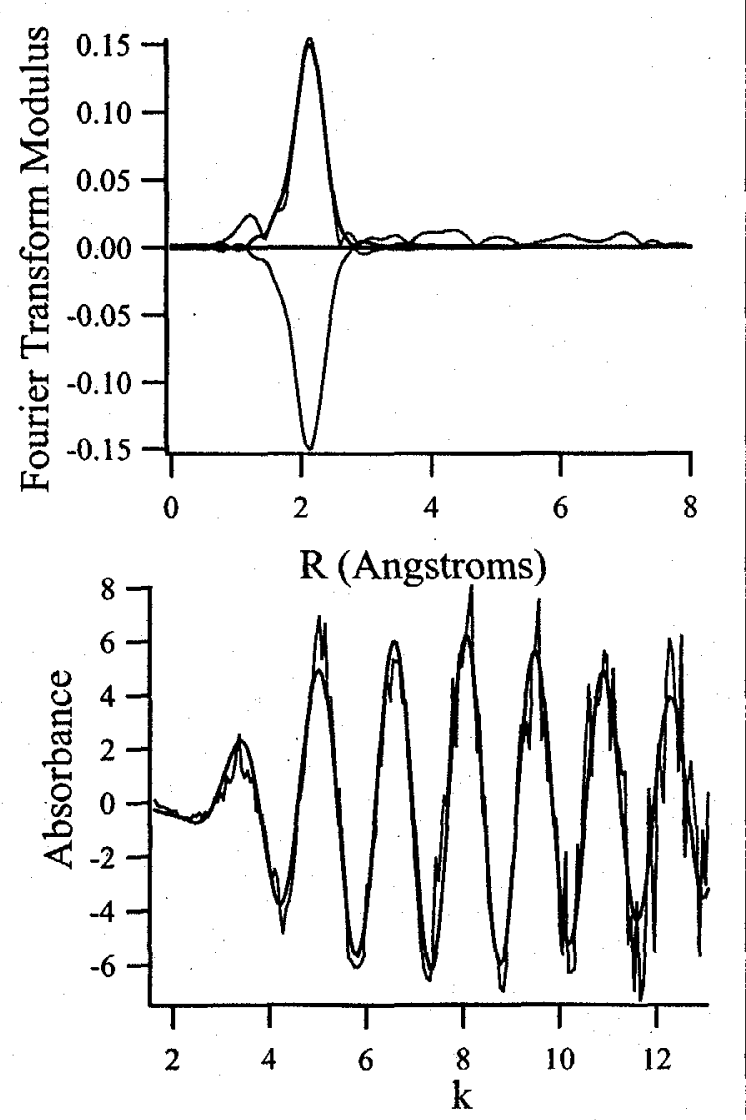

U(VI): Uranyl oxygens at $1.75 \AA, n=2$

Chlorine shell at $2.66 \AA, n=2.66$
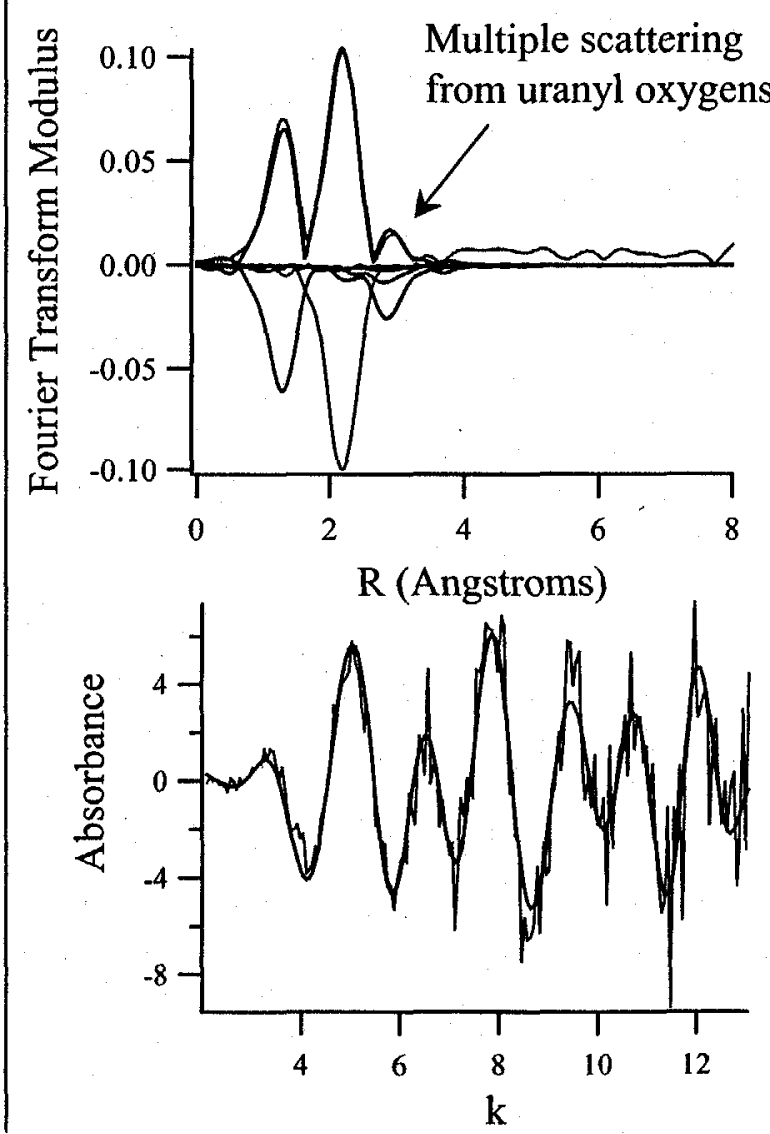

-U (IV) data were obtained from both acidic and basic melts. There was no difference between the structural parameters from acidic and basic melts.

-An Al shell was not seen in the EXAFS data, however the data could not rule out complexation by $\mathrm{AlCl}_{4}$. The small scattering cross section of $\mathrm{Al}$ combined with the large distance for an $\mathrm{Al}$ shell results in a weak contribution to the EXAFS from Al. Data with higher $\mathrm{S} / \mathrm{N}$ ratio extending to higher $\mathrm{k}$ would detect an $\mathrm{Al}$ shell.

\section{Los Alamos}

Nuclear Materials Technology Division 


\section{Oxidation States Determined from Xanes Edge}

Desired XANES Edge Positions of the Series of Uranium Oxidation States Available in Room Temperature Ionic Liquids, Especially the V Oxidation State without the Uranyl Oxygens

-Seven samples sent to SSRL for XAS studies: 2 U(III), 3 U(V), and 2 U(VI)

-XANES edge energies and the distance of chlorine shells from the EXAFS suggest that the U(III) samples were oxidized to U(IV) and the U(V) samples were reduced to U(IV). Absorption spectroscopy verified these observations.

-Need to modify existing XAS sample holders to be inert to this media.
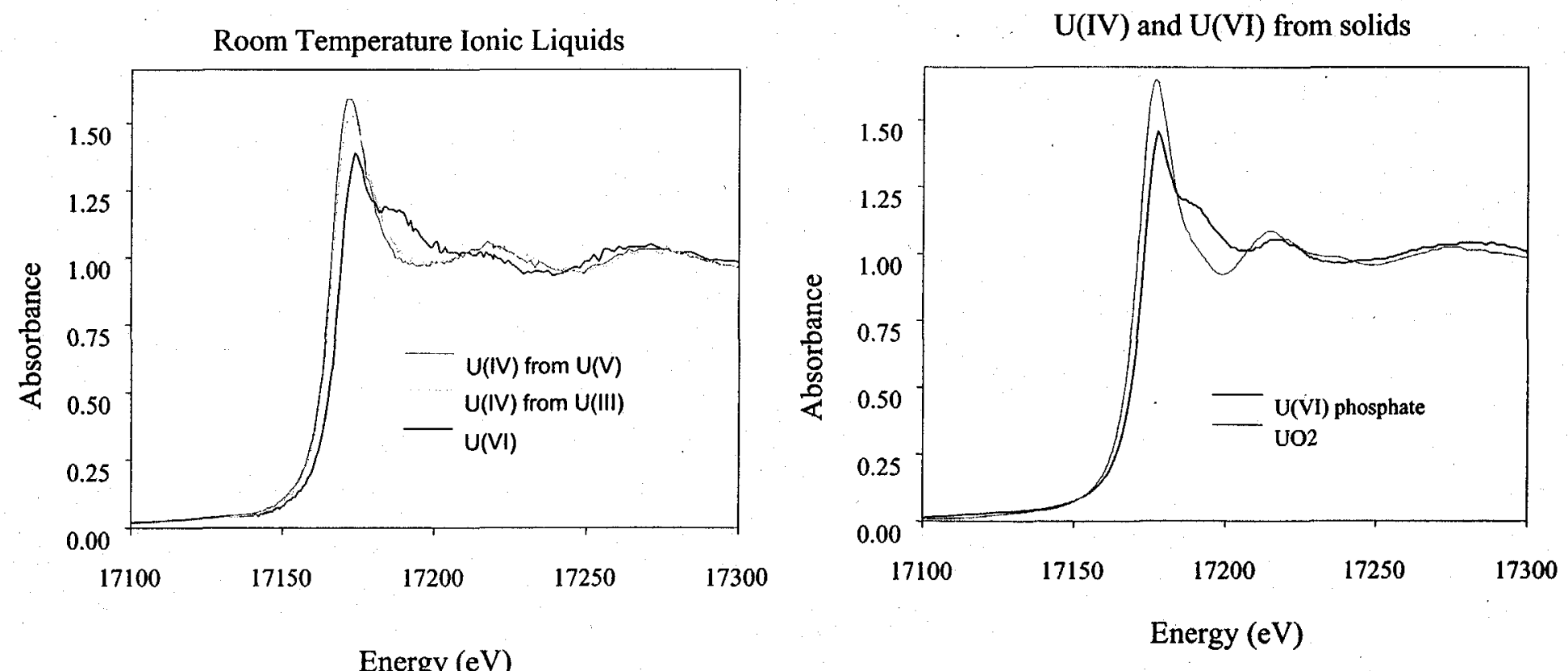

Energy (eV) 


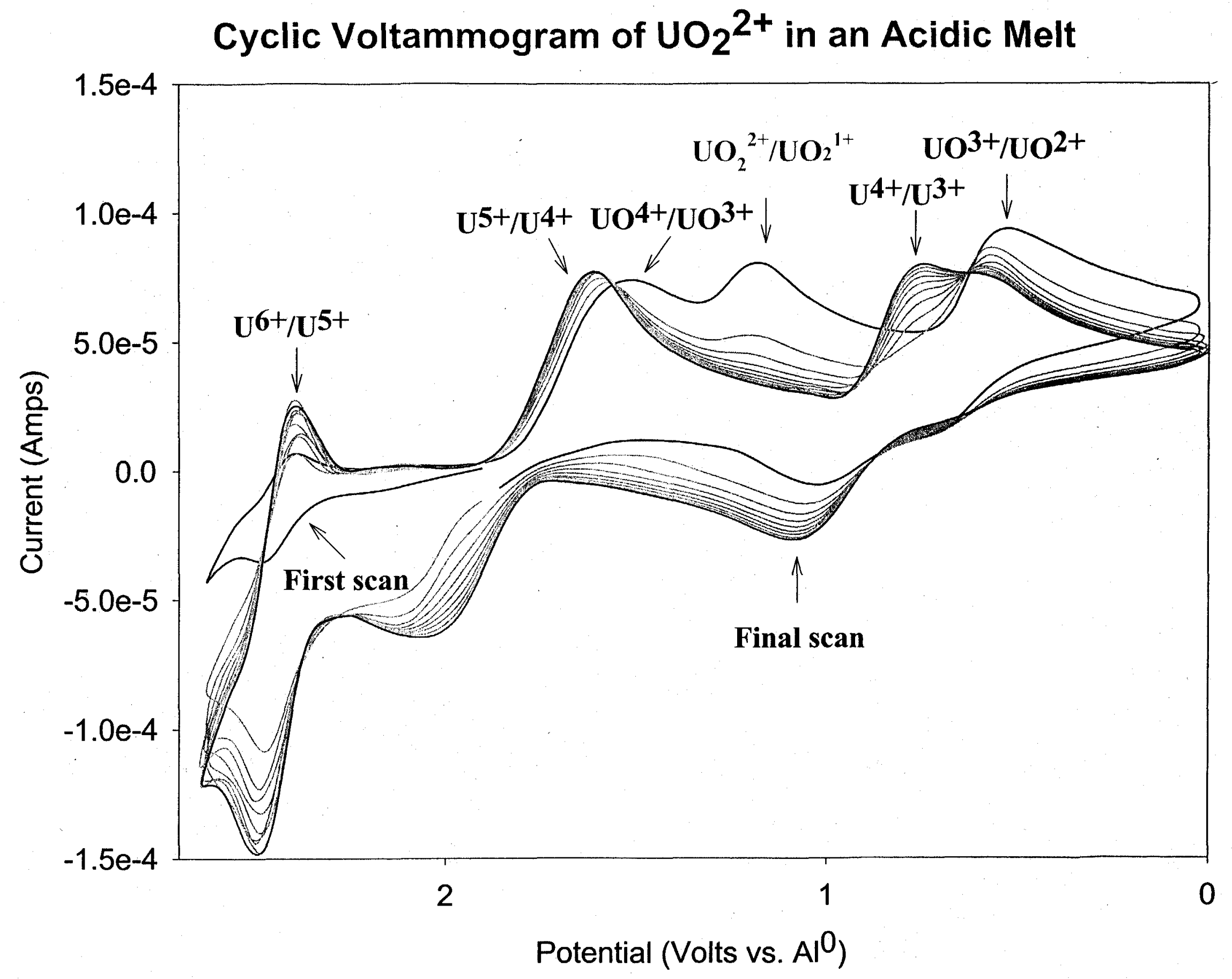

